This is the author version of an article originally published in the International Urogynecology Journal and Pelvic Floor Dysfunction 2010;21(11):1413-1421 http://www.springerlink.com/content/d10316t026637340/

Systematic review of the efficacy and safety of using mesh in surgery for uterine or vaginal vault prolapse

Xueli Jia ${ }^{\mathrm{a}}$, Cathryn Glazener ${ }^{\mathrm{a}}$, Graham Mowatt ${ }^{\mathrm{a}}$, David Jenkinson ${ }^{\mathrm{a}}$, Cynthia Fraser ${ }^{\mathrm{a}}$, Christine Bain $^{\mathrm{b}}$, Jennifer Burr ${ }^{\mathrm{a}}$

${ }^{\mathrm{a}}$ Health Services Research Unit, University of Aberdeen, Aberdeen, UK

${ }^{\mathrm{b}}$ Aberdeen Royal Infirmary, NHS Grampian, Aberdeen, UK

Correspondence: Xueli Jia, Health Services Research Unit, University of Aberdeen, Aberdeen, AB25 2ZD, UK. Email x.jia@abdn.ac.uk

\title{
Disclosure of Interests
}

There is no conflict of interest. 


\section{Abstract}

Introduction The aim of this study is to estimate efficacy and safety of mesh in surgery for uterine or vault prolapse.

Methods Seventeen electronic databases were searched for relevant studies that published from 1980 onwards.

Results Fifty-four studies involving 7054 women were included. For sacrocolpopexy (average follow up 23 months), the risk of clinical recurrence ranged from $0 \%$ to $6 \%$, persistent symptoms ranged from $3 \%$ to $31 \%$, and mesh erosion from $0 \%$ to $12 \%$. For infracoccygeal sacropexy (average follow up 13 months), the risk of clinical recurrence ranged from $0 \%$ to $25 \%$, persistent symptoms from $2 \%$ to $21 \%$, and mesh erosion $0 \%$ to $21 \%$. Limited evidence was available for sacrocolpoperineopexy and uterine suspension sling to draw reliable estimates.

Conclusion Sacrocolpopexy was associated with a low risk of recurrence but with a relatively high risk of mesh erosion. Ranges of estimates for outcomes for other mesh techniques were wide.

(Word limit set by journal: 150)

Keywords efficacy, mesh, mesh erosion, NICE, pelvic organ prolapsed, safety, systematic review

\section{Brief summary Sacrocolpopexy was associated with a low risk of recurrence but a} higher risk of mesh erosion. Ranges of estimates for other mesh techniques were wide.

(Word limit set by journal: 25) 


\section{Introduction}

Prolapse of the uterus or vaginal vault (middle compartment) affects a woman's health by its local physical effects (pressure, bulging, heaviness or discomfort) or its effect on urinary, bowel or sexual function. Current treatment options for uterine or vault prolapse include pelvic floor muscle training,[1] use of pessaries (mechanical devices such as rings or shelves)[2] and surgery.[3]

Prolapse surgery not involving mesh includes hysterectomy, cervical amputation, and uterine/vault attachment with sutures to the pelvic ligaments. Surgical techniques using mesh include sacrocolpopexy, sacrocolpoperineopexy, infracoccygeal sacropexy (also known as Posterior IntraVaginal Slingplasty, IVS), and uterine suspension sling.

In sacrocolpopexy, the vaginal vault is attached with a mesh bridge to the periosteum of the sacral promontory. If this is carried out at the same time as hysterectomy, the aim of the sacrocolpopexy is prophylaxis to prevent future vault prolapse. Sacrocolpoperineopexy is a variation of sacrocolpopexy where extra mesh is inserted between the posterior vaginal wall and the rectum down to the perineum. Use of sacrocolpoperineopexy is contentious because the relatively large amount of mesh may increase risks of mesh erosion. In infracoccygeal sacropexy, the uterus or vault is suspended using a mesh tape with the aid of a trochar (tunnelling device) through each of the ischiorectal fossae. The uterine suspension sling technique can only be used in women who wish to conserve their uterus, i.e. for uterine prolapse repair. In this procedure, the uterus is attached with mesh to pelvic ligaments or to the periosteum of the sacral promontory.

Both the efficacy and safety of mesh in surgery for uterine or vault prolapse are uncertain. This report presents the estimated efficacy and safety of mesh in surgery for uterine or vault prolapse. It is based on a review that was commissioned through the UK 
National Institute for Health and Clinical Excellence (NICE) Interventional Procedures Programme. An electronic version of the full report is available from the NICE website.[4]

\section{Methods}

\section{Search strategy}

We searched electronic databases, conference proceedings and relevant websites, contacted 11 manufacturers, and scrutinised bibliographies of retrieved papers to identify reports of published and ongoing studies on the efficacy and safety of mesh in surgery for uterine or vault prolapse repair. Searches, designed to be highly sensitive and using both controlled vocabulary and free-text terms, were restricted to publications from 1980 onwards, to those published in the English language and, for conference proceedings, to randomised controlled trials published from 2005 onwards. Studies that reported only procedures without mesh were not identified separately. Full details of the search strategies used are reproduced in the original report[4] or are available from the authors.

The databases searched were: Medline (1980 - Nov Wk 2 2007), Medline In-Process (4 $4^{\text {th }}$ Jan 2008), EMBASE (1980 - 2008 Wk 1), Biosis (1985 - $3^{\text {rd }}$ Jan 2008), Science Citation Index (1980 $-5^{\text {th }}$ Jan 2008), Cochrane Controlled Trials Register (The Cochrane Library, Issue 4 2007), and ISI Conference Proceedings (1990 - 11 ${ }^{\text {th }}$ Feb 2008) as well as current research registers (National Research Register (Issue 2, 2007), Current Controlled Trials (Jan 2008) and Clinical Trials (Jan 2008). Additional databases searched for systematic reviews and other background information included the Cochrane Database of Systematic Reviews (The Cochrane Library, Issue 4, 2007), Database of Abstracts of Reviews of Effectiveness (Jan 2008) and the HTA Database (Jan 2008). Conference proceedings of major urogynaecological organisations (American Urogynecologic Society (2005-6), American Urological Association (2005-7), European Association of Urology (2005-7), European 
Society of Gynecological Endoscopy (2005-6), International Continence Society (2005-7) and International Urogynecological Association (2005-7) were scrutinised.

\section{Inclusion and exclusion criteria}

One reviewer screened titles/abstracts. Any uncertainties were discussed with a second reviewer and consensus was reached. Full text copies of all reports deemed to be potentially relevant were obtained and assessed by the main reviewer for inclusion.

Full-text RCTs, RCTs published as conference abstracts from 2005 onwards, nonrandomised comparative studies, and case series using mesh were sought. As the volume of literature for sacrocolpopexy was substantial, only case series with a sample size of at least 100 women were included. There was no sample size restriction placed on case series that reported other mesh techniques because the volume of literature for these techniques was very limited.

Case series with a mean follow up of at least one year were included for both efficacy and safety. Case series with a mean follow up of less than one year were included for safety outcomes only. We considered one year to be a minimum adequate period of time in which to assess the efficacy of prolapse repair.

The participants were women undergoing uterine or vault prolapse surgery. Studies of women with cancer or with prolapse caused by congenital anomalies, inherited conditions, or creation of a neovagina were excluded. Studies with women undergoing other concomitant operations, such as anterior or posterior vaginal wall prolapse repair or antiincontinence procedures were included providing the main indication for surgery was uterine or vault prolapse.

We considered all surgical techniques for uterine or vault prolapse repair which involved the use of mesh. There were no restrictions on the type of mesh used. For RCTs 
and non-randomised comparative studies, the comparators were any other surgical techniques with or without mesh.

The primary outcomes for efficacy were patient-reported persistent prolapse symptoms and clinician-reported recurrence of prolapse at the original site measured with a validated quantitative tool, e.g. the Pelvic Organ Prolapse-Quantification (POP-Q) system or Baden-Walker system. Secondary outcomes for efficacy included: new (de novo) prolapse at other sites that were free of prolapse before surgery; the need for repeat surgery for prolapse (both recurrent at the same site and de novo); persistent urinary symptoms; persistent bowel symptoms; and persistent sexual symptoms. For urinary, bowel, and sexual symptoms, only women who reported these symptoms at baseline were counted. If possible, only women who were sexually active were considered for sexual function outcomes.

The primary outcome for safety was mesh erosion. Secondary outcomes included: blood loss; damage to surrounding organs during the operation; an operation for mesh erosion or removal; new urinary, bowel or sexual symptoms; and infection. For new urinary, bowel or sexual symptoms, only women who were free of these symptoms at baseline were considered for these outcomes.

We also considered other serious and minor adverse effects not otherwise specified, operation time, and hospital stay. Details on these outcomes are provided in the full report.[4]

\section{Data extraction and quality assessment}

Data extraction and methodological quality assessment of the RCTs were conducted by two reviewers (XJ, CG) independently. The main reviewer (XJ) extracted data and assessed the quality of the remaining studies (due to resource constraints imposed by the review timelines). Two separate quality assessment checklists were used according to study design. Both checklists were developed by the Review Body for Interventional Procedures (ReBIP; Health 
Services Research Units at the Universities of Aberdeen and Sheffield), an independent review body that carries out systematic reviews for NICE's Interventional Procedures Programme. The checklists were adapted from several sources.[5-7]

\section{Data analysis}

Four techniques that use mesh were identified: sacrocolpopexy, sacrocolpoperineopexy, infracoccygeal sacropexy, and uterine suspension sling. Data analyses were conducted separately for each of the technique, and for each technique, data were presented separately for three subgroups of women according to the type of prolapse being repaired: uterine prolapse; vault prolapse; and uterine and/or vault prolapse (where the data were not reported separately).

Meta-analyses were conducted of full-text RCTs, RCTs available as conference abstracts, and non-randomised comparative studies (using Cochrane Collaboration Review Manager, RevMan 4.3 software). These allowed the efficacy and safety of procedures using mesh versus procedures without mesh, and between different techniques that used mesh, to be compared directly. All tests of significance were performed at the $5 \%$ level. For each outcome, the median and the range of the event rates were calculated by study design (RCTs, non-randomised comparative studies, case series/registries). This required each arm of an RCT or comparative study to be considered as a separate case series.

Pre-specified subgroup analyses were planned for different surgical approaches (vaginal; open abdominal; and laparoscopic), different mesh types (non-absorbable synthetic mesh; absorbable synthetic mesh; biological absorbable graft; and combined mesh containing both absorbable and non-absorbable material) and for women having primary versus secondary repairs. 


\section{Results}

\section{Number and type and quality of included studies}

From the initial 853 publications identified by the search strategy, 54 studies (reported in 60 publications) were included, of which 5 were full-text RCTs,[8-12] 3 were RCTs available as conference abstracts,[13-15] 17 were non-randomised comparative studies,[16-32] and 29 were case series.[33-61] Seven manufacturers provided relevant studies, all of which had already been identified by our searches. The screening process is summarised in Figure 1. Appendix 1 to 4 show details of study design, methods, participants, and interventions for sacrocolpopexy, sacrocolpoperineopexy, infracoccygeal sacropexy, and uterine suspension sling. Two studies involving 238 women reported a mixture of above techniques but did not report them separately.[20,40] Details and results of these two studies are available in the full report.[4] Seven ongoing RCTs[62-67] (personal communication: A Griffiths, Johnson \& Johnson, 2007), one ongoing registry,[68] and one ongoing case series[66] were also identified.

The included studies took place during the period 1991 - 2007 in 16 countries. Overall, 7054 women were treated in total, of whom 4456 were treated with sacrocolpopexy, 282 with sacrocolpoperineopexy, 976 with infracoccygeal sacropexy, 159 with uterine suspension sling, 238 a mixture of the above mesh techniques, and 943 with no-mesh techniques.

Across studies, the average age of the women was 61 years. Women who were treated with uterine suspension sling (a technique allows uterus to be preserved for future pregnancy) were younger (average age 37 years) than those treated with other techniques (average age around 65 years). Only six studies provided information on whether the procedures were primary or secondary, of which two presented data on primary surgery alone. 
We assessed the methodological quality of the full-text studies only because the abstracts only provided limited information about quality. The study quality of RCTs, nonrandomised comparative studies, and case series is summarised in Figure S1, S2 and S3 respectively (supplementary data).

\section{Sacrocolpopexy}

Thirty-two studies (4 full-text RCTs,[8-11] 1 RCT available as conference abstract,[13] 15 non-randomised comparative studies,[16-19,21-26,28-32] and 12 case series with sample sizes over 100) involving a total of 4456 women provided data on sacrocolpopexy. Two studies[13,19] reported on uterine prolapse (hysterectomy followed by sacrocolpopexy in the same procedure), seven studies reported vault prolapse (sacrocolpopexy alone),[9,11,21,26,29,42,47] two studies reported uterine and vault prolapse separately,[23,61] and 21 studies[8,10,16-18,22,24,25,28,30-32,35-39,46,51,57,59] reported data from women having uterine and/or vault prolapse together (Appendix 1). Mesh types varied across studies. The median (range) of mean follow up across these 32 studies was 23 months (8 to 66 months). Table 1 shows, for each type of study, the medians and ranges of event rates across studies for primary outcomes for sacrocolpopexy.

\section{Efficacy}

One small RCT involving 89 women with vault prolapse compared sacrocolpopexy (mesh) with sacrospinous colpopexy (no mesh): differences in risk of persistent symptom (RR 0.70, 95\% CI 0.17 to 2.95) and risk of prolapse recurrence (RR 0.23 , 95\% CI 0.05 to 1.04 ) were not statistically significant.[11]

The risks of recurrence across all study designs ranged from $0 \%$ to $6 \%$ in 14 studies involving 1054 women (median 1.2\%, Table 1), while the risks for persistent prolapse 
symptoms ranged from 3\% to 31\% in 9 studies involving 638 women (median 22\%). In 4 studies involving 451 women, risks of needing a further operation for recurrent or de novo prolapse ranged from $0 \%$ to $14 \%$ (median $8 \%$ ). Estimates for other outcomes were based on single studies only.

\section{Safety}

The risk of mesh erosion ranged from $0 \%$ to $12 \%$ (median $5.4 \%$, 27 studies, $n=2922$, Table 1). Zero to $11 \%$ of women required an operation for mesh erosion (median 3.8\%, 17 studies, $\mathrm{n}=2074$ ). In studies reporting mesh erosion, most studies used non-absorbable synthetic mesh (Table 2). The median mesh erosion rates across studies were $4.0 \%$ (range $0 \%$ to $12.0 \%$, 21 studies, $\mathrm{n}=1869$ ) for non-absorbable synthetic mesh compared with $0 \%$ (range $0 \%$ to $0.8 \%$, 5 studies, $n=229$ ) for absorbable biological graft. No studies reported mesh erosion data for absorbable synthetic mesh and only one study reported mesh erosion for combined mesh $(4.3 \%, 1 / 23)$.

For other safety outcomes, the proportion of women who required a blood transfusion for sacrocolpopexy ranged from $0 \%$ to $17 \%$ (median $1.7 \%, 19$ studies, $n=2080$ ). The range for women suffering organ damage varied from $0 \%$ to $8 \%$ (median $2.1 \%, 15$ studies, $n=1723$ ). New urinary symptoms in women who did not have these symptoms at baseline occurred in $4 \%$ to $9 \%$ (median $6.8 \%, 4$ studies, $n=294)$. The estimate for new bowel symptoms $(1 \%$, 2/178) was based on a single study, and the estimate for new sexual symptoms (range $9 \%$ to $15 \%, \mathrm{n}=87$ ) was based on two small studies. The range for infection was wide, which reflected the variety of ways used to define it ( $0.8 \%$ to $68 \%, 17$ studies, $n=1391)$.

Data were available for meta-analysis comparing blood transfusion, damage to surrounding organs, infection and new urinary symptoms between sacrocolpopexy (mesh) 
and sacrospinous colpopexy (no mesh). There was not enough evidence to demonstrate a difference in any of these outcomes between the operations.[4]

\section{Sacrocolpoperineopexy}

Two studies involving 442 women reported on sacrocolpoperineopexy.[31,58] (Appendix 2). Table 3 shows the event rates for primary outcomes for sacrocolpoperineopexy. Neither of the two studies gave details of uterine and vault prolapse separately. Risks of mesh erosion reported by these two studies were similar (8.5\% in 118 women in 6 months and $8.3 \%$ in 169 women in 14 months).

\section{Infracoccygeal sacropexy (posterior IVS)}

Fourteen studies (2 RCTs available as conference abstracts,[14,15] 1 non-randomised comparative study,[27] 2 case series with sample sizes $\$ 100,[45,60]$ and 9 case series with sample sizes $<100[41,43,44,48,52-56])$ involving 976 women provided data on infracoccygeal sacropexy. One study[27] reported uterine repair (uterus conserved), $5[14,41,43,44,53]$ reported vault repair, onereported uterine and vault repairs separately[56], and $7[15,45,48,52,54,55,60]$ studies reported uterine and vault repairs together (Appendix 3). The median follow up across these 14 studies was 13 months (range 5 to 30 months). The ranges of event rates for primary outcomes are shown in Table 4. Meta-analysis was not possible because the comparative studies used different comparators.

\section{Efficacy}

The proportion of women with persistent prolapse symptoms ranged from $2 \%$ to $21 \%$ (median 8.8\%, $\mathrm{n}=262,3$ studies) after infracoccygeal sacropexy, whereas the range for prolapsed recurrence was $0 \%$ to $25 \%$ (median $4.8 \%$, 9 studies, $n=402)$. In 3 studies ( $\mathrm{n}=288$ ), 
the re-operation rate varied from none to $30 \%$ (median 7.9\%). Estimates for other outcomes were based on single studies with few women.

\section{Safety}

The risks of mesh erosion ranged from $0 \%$ to $21 \%$ (median $6.7 \%, 11$ studies, $n=889$ ), and $0.3 \%$ to $17 \%$ of women needed an operation for mesh erosion (median $7.2 \%, 6$ studies, $\mathrm{n}=678$ ). All studies reporting mesh erosion used non-absorbable synthetic mesh. The need for blood transfusion ranged from $0 \%$ to $2 \%$ ( 7 studies, $n=383$ ). The risks of organ damage ranged from $0 \%$ to $2.7 \%$ (median $0 \%$, 9 studies, $n=684$ ). Little evidence was available for new urinary symptoms, bowel symptoms, and sexual symptoms in women who did not have these symptoms at baseline. Infection ranged from $0 \%$ to $9 \%$ (8 studies, $n=698$ ).

\section{Uterine suspension sling}

Six studies[12,19,33,34,49,50] involving 239 women reported on uterine suspension sling operations. One was a full-text RCT,[12] one was a non-randomised comparative study,[19] and four were case series[33,34,49,50] (Appendix 4). All of the case series had a sample size of less than 100. Five of the six studies reported sacrohysteropexy (uterus suspended to the sacrum with a mesh bridge) and the other[49] reported a different technique (suspending the uterus to the pectineal ligaments). The median follow up across the six studies was 33 months (12 to 95 months). Meta-analysis was not possible because the comparative studies used different comparators.

\section{Efficacy, safety, operation time and hospital stay}

Table 5 shows the event rates for primary outcomes. The range of persistent prolapse symptoms was wide ( $0 \%$ to $39 \%$, median $3.3 \%$, 3 studies, $n=91)$. The risks of recurrence 
ranged from $0 \%$ to $8 \%$ (median $3.3 \%, 5$ studies, $n=136$ ), while the risks of requiring a reoperation for prolapse ranged from $0 \%$ to $22 \%$ (median $3.3 \%, 3$ studies, $n=107$ ). Little evidence was available for estimating other efficacy outcomes or any of the safety outcomes.

\section{Discussion}

\section{Summary of the evidence}

The review indicated that although sacrocolpopexy is associated with an apparent risk of clinical recurrence ranging from $0 \%$ to $6 \%$ (at an average follow up of two years), the incidence of persistent prolapse symptoms (range 3\% to 31\%) and need for a further prolapse operation (range $2 \%$ to $25 \%$ ) were relatively high. There were risks from adverse effects such as mesh erosion (range $0 \%$ to $12 \%$ ), which often required a further operation for mesh erosion (range $1 \%$ to $11 \%$ ). Non-absorbable mesh was associated with a higher risk of mesh erosion (median $4.0 \%$, range $0 \%$ to $12.0 \%$ ) compared with absorbable biological graft (median $0 \%$, range $0 \%$ to $0.8 \%$ ).

Sacrocolpoperineopexy was associated with $8 \%$ of mesh erosion at an average follow up of one year. Little evidence was available for other outcomes.

For infracoccygeal sacropexy, persistent symptoms ranged from $2 \%$ to $21 \%$ at an average follow up of one year, clinical recurrence varied from $0 \%$ to $25 \%$, mesh erosion from $0 \%$ to $21 \%$, and operation for mesh erosion from $2 \%$ to $17 \%$.

For uterine suspension sling, the clinical recurrence rates ranged from $0 \%$ to $8 \%$ at an average follow up of three years, whereas persistent symptoms ranged from $0 \%$ to $39 \%$. However, little evidence was available for safety outcomes.

\section{Assumptions, limitations, and uncertainties}


We aimed to review separately data from women having uterine prolapse and vault prolapse, because the operations, and hence the efficacy and safety, might be different in these two populations. However, the majority of the studies (32/54) reported data from women having uterine or vault repairs without separating the groups. As there was limited evidence for uterine prolapse repair and for vault prolapse repair alone, we did review evidence from studies that reported a mixture of uterine and vault prolapse.

We did not separate data by surgical approach. We are aware that the laparoscopic approach is gaining in popularity. This could be applied in sacrocolpopexy, sacrocolpoperineopexy, or uterine suspension sling. A small proportion of the included studies reported that the operations were done laparoscopically and were all for sacrocolpopexy $(7.5 \%, 336 / 4456) \cdot[25,26,29,32,46]$

It is important to determine whether safety and efficacy of mesh differ in women having primary versus recurrent prolapse repairs. However, of the 54 included studies, only two case series[35,61] reported exclusively on women having primary repairs. Another four studies[18,34,49,51] reported the case mix of primary and secondary operations but did not report outcome data separately for the two groups. It is likely that the remaining 48 studies included women having both primary and secondary surgery but this was not reported.

There was a very limited number of RCTs available $(20 \%, 11 / 54)$ of which five were available only as conference abstracts. The number of RCTs in each subgroup (by two types of prolapse, and by four different surgical techniques) was even smaller (Appendices 1 to 4). Data were therefore too few to compare efficacy and safety between surgical techniques using mesh (each type) and no mesh and between different mesh techniques.

We pragmatically considered one year as an adequate minimum period of time to assess the efficacy of middle compartment prolapse repair. However, as the mean time to reoperation is 12 years[69] one year may be too short to judge success. Therefore failure rates 
at one year may not be representative of longer-term efficacy. Prospective studies will require extended follow up to assess meaningful mesh failure rates.

Nevertheless, the results were considered generalisable as the majority of studies recruited participants from a spectrum of routine practice, without restrictions for the severity of prolapse or other patient characteristics.

\section{Conclusions and implications}

In general, sacrocolpopexy was associated with a low risk of recurrence, but the risks of persistent prolapse symptoms, re-operation, and mesh erosion were relatively high. The estimates for the efficacy and safety outcomes for infracoccygeal sacropexy were wide. There was only limited evidence for efficacy and safety for sacrocolpoperineopexy or uterine suspension sling.

In consequence, in January 2009, NICE (UK) recommended that, for all but sacrocolpopexy for vaginal vault prolapse repair,[70] 'special arrangements for clinical governance, consent and audit or research' should be used.[71-74] The implications are that the 'clinical governance leads in their Trusts should be informed, and patients need to be explicitly counselled about the uncertainty regarding safety and efficacy. Clear written information must be provided'. NICE also recommend that clinicians should enter details about all patients undergoing the procedures on the British Society for Urogynaecology Database so that a UK-wide audit of current practice can be carried out.

In addition, rigorous RCTs, with adequate power to detect clinically meaningful differences and long-term outcomes, are needed to determine the comparative efficacy of mesh techniques and their optimal place in the treatment of middle compartment prolapse. They should use validated patient-reported outcome measures, primarily to compare the 
failure rates and safety profiles, between mesh and no-mesh techniques, between different types of mesh techniques, and between different types of mesh.

(Word count: 3503). 


\section{Acknowledgements}

The authors thank Adrian Grant (Health Services Research Unit, University of Aberdeen) for commenting on the study design; Georgios Lyratzopoulos and Sally Wortley (Interventional Procedures Programme, National Institute for Health and Clinical Excellence (NICE), UK) for commenting on the draft. James Browning (Mpathy Medical Devices Ltd.), Christine Clarke (Bard Ltd.), Hazel Edwards (American Medical Systems (UK), Ltd.), Adrian Griffiths (Johnson \& Johnson Medical Ltd.), William Hynes (WL Gore \& Associates (UK) Ltd.), and Coloplast Ltd. for providing properties of mesh produced by the manufacturers and published studies relating to mesh; and Paul Moran for providing additional information for a study identified from the National Research Register database.

\section{Contribution to Authorship}

XJ and CG wrote this paper and all authors contributed to its content. XJ screened the search results, contacted manufacturers, assessed studies for inclusion, undertook data abstraction and quality assessment, conducted data analysis, and drafted the Interventional Procedures review on which this paper is based. CG drafted the scope, provided advice on study inclusion, determined outcome categories, drafted the background and methods sections of the review, and commented on drafts of the review. GM commented on the scope of the review, drafted letters for contacting mesh manufacturers for additional information, supervised the conduct of the review, and commented on drafts of the review. DJ provided advice on statistical analysis, checked the analysis results, and commented on drafts of the review. CF developed and ran the literature search strategies, obtained papers, formatted the references, and drafted sections concerning search strategies and search results. CB provided specialist advice on classification of mesh techniques, and commented on drafts of the review. JB supervised the conduct of the review, and commented on drafts of the review. 


\section{Funding}

This manuscript is based on a systematic review commissioned and funded by the National Institute for Health and Clinical Excellence through its Interventional Procedures Programme. The Health Services Research Unit receives a core grant from the Chief Scientist Office of the Scottish Government Health Directorates. The views expressed are those of the authors and not necessarily those of the funding bodies. 


\section{References}

1. Hagen S, Stark D, Maher C, Adams EJ (2006). Conservative management of pelvic organ prolapse in women. Cochrane Database of Systematic Reviews Issue 4. Art. No.: CD003882. DOI: 10.1002/14651858.CD003882.pub3.

2. Adams EJ, Thomson A, Maher C, Hagen S (2004). Mechanical devices for pelvic organ prolapse in women. Cochrane Database of Systematic Reviews Issue 2. Art. No.: CD004010. DOI: 10.1002/14651858.CD004010.pub2.

3. Maher C, Baessler K, Glazener CM, Adams EJ, Hagen S (2007). Surgical management of pelvic organ prolapse in women. Cochrane Database of Systematic Reviews Issue 3. Art. No.: CD004014. DOI: 10.1002/14651858.CD004014.pub3.:

4. Systematic review of the efficacy and safety of using mesh or grafts in surgery for uterine or vaginal vault prolapse (2008). National Institute for Health and Clinical Excellence, London [accessed September 2009]. Available from : URL:

http://www.nice.org.uk/guidance/index.jsp?action=download\&o=41728.

5. Systematic reviews: CRD's guidance for undertaking systematic reviews in health care (2009). Centre for Reviews and Dissemination, University of York [accessed September 2009]. Available from: URL:

http://www.york.ac.uk/inst/crd/SysRev/!SSL!/WebHelp/SysRev3.htm.

6. Downs SH, Black N. (1998). The feasibility of creating a checklist for the assessment of the methodological quality both of randomised and non-randomised studies of health care interventions. J Epidemiol Community Health 52:377-384. 
7. Verhagen AP, de Vet HC, de Bie RA, Kessels AG, Boers M, Bouter LM et al (1998). The Delphi list: a criteria list for quality assessment of randomized clinical trials for conducting systematic reviews developed by Delphi consensus. J Clin Epidemiol 51:1235-1241.

8. Benson JT, Lucente V, McClellan E (1996). Vaginal versus abdominal reconstructive surgery for the treatment of pelvic support defects: a prospective randomized study with long-term outcome evaluation. Am J Obstet Gynecol 175:1418-1421.

9. Culligan PJ, Blackwell L, Goldsmith LJ, Graham CA, Rogers A, Heit MH (2005). A randomized controlled trial comparing fascia lata and synthetic mesh for sacral colpopexy. Obstet Gynecol 106:29-37.

10. Lo T-S (1998). Abdominal colposacropexy and sacrospinous ligament suspension for severe uterovaginal prolapse: A comparison. J Gynecol Surg 14:59-64.

11. Maher CF, Qatawneh AM, Dwyer PL, Carey MP, Cornish A, Schluter PJ (2004). Abdominal sacral colpopexy or vaginal sacrospinous colpopexy for vaginal vault prolapse: a prospective randomized study. Am J Obstet Gynecol 190:20-26.

12. Roovers JP, van der Vaart C, van der Bom JG, van Leeuwen JH, Scholten PC, Heintz PM (2004). A randomised controlled trial comparing abdominal and vaginal prolapse surgery: effect on urogenital function. BJOG 111:50-56.

13. Braun H, Fernandez M, Delloro A, Gonzalez F, Cuevas R, Rojas I (2007). Prospective randomised study to compare colposacropexy and Mayo McCall technique in the correction of severe genital central prolapse. Int Urogynecol J 18:S12. 
14. Meschia M, Barbacini P, Longatti D, Gattei U, Pifarotti P (2005). Randomized comparison between infracoccygeal sacropexy (posterior IVS) and sacrospinous ligament fixation in the management of vault prolpase. Int Urogynecol J 16:S54.

15. Tayrac R, Bader G, Deffieux X, Fazel A, Mathe ML, Fernandez H (2006). A prospective randomized study comparing posterior IVS and sacrospinous suspension for the surgical treatment of uterine or vaginal vault prolapse. Int Urogynecol J 17:S234-S235.

16. Altman D, Anzen B, Brismar S, Lopez A, Zetterstrom J (2006). Long-term outcome of abdominal sacrocolpopexy using xenograft compared with synthetic mesh. Urology 67:719724.

17. Bai SW, Kwon HS, Chung DJ (2006). Abdominal high uterosacral colpopexy and abdominal sacral colpopexy with mesh for pelvic organ prolapse. Int J Gynecol Obstet 92:147-148.

18. Begley JS, Kupferman SP, Kuznetsov DD, Kobashi KC, Govier FE, McGonigle KF et al (2005). Incidence and management of abdominal sacrocolpopexy mesh erosions. Am J Obstet Gynecol 192:1956-1962.

19. Costantini E, Mearini L, Bini V, Zucchi A, Mearini E, Porena M (2005). Uterus preservation in surgical correction of urogenital prolapse. Eur Urol 48:642-649.

20. Demirci F (2007). Perioperative complications in abdominal sacrocolpopexy and vaginal sacrospinous ligament fixation procedures. Int Urogynecol J Pelvic Floor Dysfunct 18:257261. 
21. Govier FE, Kobashi KC, Kozlowski PM, Kuznetsov DD, Begley SJ, McGonigle KF et al. (2005). High complication rate identified in sacrocolpopexy patients attributed to silicone mesh. Urology 65:1099-1103.

22. Gregory WT, Otto LN, Bergstrom JO, Clark AL (2005). Surgical outcome of abdominal sacrocolpopexy with synthetic mesh versus abdominal sacrocolpopexy with cadaveric fascia lata. Int Urogynecol J 16:369-374.

23. Griffis K, Evers MD, Terry CL, Hale DS (2006). Mesh erosion and abdominal sacrocolpopexy: A comparison of prior, total, and supracervical hysterectomy. J Pelvic Med Surg 12:25-30.

24. Hardiman PJ, Drutz HP (1996). Sacrospinous vault suspension and abdominal colposacropexy: success rates and complications. Am J Obstet Gynecol 175:612-616.

25. Hsiao KC (2007). Comparison of laparoscopic and abdominal sacrocolpopexy for the treatment of vaginal vault prolapse. J Endourol 21:926-930.

26. Marcickiewicz J, Kjollesdal M, Engh ME, Eklind S, Axen C, Brannstrom M et al (2007). Vaginal sacrospinous colpopexy and laparoscopic sacral colpopexy for vaginal vault prolapse. Acta Obstet Gynecol Scand 86:733-738.

27. Neuman M, Lavy Y (2007). Conservation of the prolapsed uterus is a valid option: medium term results of a prospective comparative study with the posterior intravaginal slingoplasty operation. Int Urogynecol J 18:889-893.

28. Ng CC, Han WH (2004). Comparison of effectiveness of vaginal and abdominal routes in treating severe uterovaginal or vault prolapse. Singapore Med J 45:475-481. 
29. Paraiso MF, Walters MD, Rackley RR, Melek S, Hugney C (2005). Laparoscopic and abdominal sacral colpopexies: a comparative cohort study. Am J Obstet Gynecol 192:17521758.

30. Sze EH, Kohli N, Miklos JR, Roat T, Karram MM (1999). A retrospective comparison of abdominal sacrocolpopexy with Burch colposuspension versus sacrospinous fixation with transvaginal needle suspension for the management of vaginal vault prolapse and coexisting stress incontinence. Int Urogynecol J 10:390-393.

31. Visco AG, Weidner AC, Barber MD, Myers ER, Cundiff GW, Bump RC et al (2001). Vaginal mesh erosion after abdominal sacral colpopexy. Am J Obstet Gynecol 184:297-302.

32. Young SB, Kohorn EI, Braz-Martin S, Baker SP (2004). A survey of the complications of vaginal prolapse surgery performed by members of the Society Of Gynecologic Surgeons. Int Urogynecol J 15:165-170.

33. Banu LF (1997). Synthetic sling for genital prolapse in young women. Int J Gynecol Obstet 57:57-64.

34. Barranger E, Fritel X, Pigne A (2003). Abdominal sacrohysteropexy in young women with uterovaginal prolapse: long-term follow-up. Am J Obstet Gynecol 18:1245-1250.

35. Bensinger G, Lind L, Lesser M, Guess M, Winkler HA (2005). Abdominal sacral suspensions: analysis of complications using permanent mesh. Am J Obstet Gynecol 193:2094-2098.

36. Bradley CS (2007). Bowel symptoms in women 1 year after sacrocolpopexy. Am J Obstet Gynecol 197:642 e1-642 e8. 
37. Brizzolara S, Pillai-Allen A (2003). Risk of mesh erosion with sacral colpopexy and concurrent hysterectomy. Obstet Gynecol 102:306-310.

38. Culligan PJ, Murphy M, Blackwell L, Hammons G, Graham C, Heit MH (2002). Longterm success of abdominal sacral colpopexy using synthetic mesh. Am J Obstet Gynecol 187:1473-1480.

39. de Vries MJ, van Dessel TH, Drogendijk AC, de Haas I, Huikeshoven FJ (1995). Shortterm results and long-term patients' appraisal of abdominal colposacropexy for treatment of genital and vaginal vault prolapse. Eur J Obstet Gynecol Reprod Biol 59:35-38.

40. Elneil S, Cutner AS, Remy M, Leather AT, Toozs-Hobson P,Wise B (2005). Abdominal sacrocolpopexy for vault prolapse without burial of mesh: a case series. BJOG 112:486-489.

41. Farnsworth BN (2002). Posterior intravaginal slingplasty (infracoccygeal sacropexy) for severe posthysterectomy vaginal vault prolapse--a preliminary report on efficacy and safety. Int Urogynecol J 13:4-8.

42. Fedorkow DM, Kalbfleisch RE (1993). Total abdominal hysterectomy at abdominal sacrovaginopexy - a comparative-study. Am J Obstet Gynecol 169:641-643.

43. Foote AJ (2007). Infracoccygeal sacropexy. Aust N Z J Obstet Gynaecol 47:250-251.

44. Ghanbari Z, Baratali BH, Mireshghi MS (2006). Posterior intravaginal slingplasty (infracoccygeal sacropexy) in the treatment of vaginal vault prolapse. Int J Gynaecol Obstet 94:147-148.

45. Hefni M (2007). Morbidity associated with posterior intravaginal slingplasty for uterovaginal and vault prolapse. Arch Gynecol Obstet 276:499-504. 
46. Higgs P, Goh J, Krause H, Sloane K, Carey M (2005). Abdominal sacral colpopexy: an independent prospective long-term follow-up study. Aust N Z J Obstet Gynaecol 45:430-434.

47. Higgs PJ, Chua HL, Smith AR (2005). Long term review of laparoscopic sacrocolpopexy. BJOG 112:1134-1138.

48. Jordaan DJ, Prollius A, Cronje HS, Nel M (2006). Posterior intravaginal slingplasty for vaginal prolapse. Int Urogynecol J 17:326-329.

49. Joshi VM (1993). A new technique of uterine suspension to pectineal ligaments in the management of uterovaginal prolapse. Obstet Gynecol 81:790-793.

50. Leron E, Stanton SL (2001). Sacrohysteropexy with synthetic mesh for the management of uterovaginal prolapse. BJOG 108:629-633.

51. Lindeque BG, Nel WS (2002). Sacrocolpopexy--a report on 262 consecutive operations. S Afr Med J 92:982-985.

52. Oliver R, Dasgupta C, Coker A (2006). Posterior intravaginal slingplasty for vault and uterovaginal prolapse: An initial experience. Gynecol Surg 3:88-92.

53. Papa Petros PE (2001). Vault prolapse II: Restoration of dynamic vaginal supports by infracoccygeal sacropexy, an axial day-case vaginal procedure. Int Urogynecol J Pelvic Floor Dysfunct 12:296-303.

54. Petros PE, Richardson PA (2005). Tissue Fixation System posterior sling for repair of uterine/vault prolapse -- a preliminary report. Aust N Z J Obstet Gynaecol 45:376-379. 
55. Sentilhes L, Sergent F, Resch B, Verspyck E, Descamps P, Marpeau L (2007). Midterm Follow-up of High-Grade Genital Prolapse Repair by the Trans-obturator and Infracoccygeal Hammock Procedure after Hysterectomy. Eur Urol 51:1065-1072.

56. Sivaslioglu AA, Gelisen O, Dolen I, Dede H, Dilbaz S, Haberal A (2005). Posterior sling (infracoccygeal sacropexy): An alternative procedure for vaginal vault prolapse. Aust N Z J Obstet Gynaecol 45:159-160.

57. Snyder TE, Krantz KE (1991). Abdominal-retroperitoneal sacral colpopexy for the correction of vaginal prolapse. Obstet Gynecol 77:944-949.

58. Su KC, Mutone MF, Terry CL, Hale DS (2007). Abdominovaginal sacral colpoperineopexy: patient perceptions, anatomical outcomes, and graft erosions. Int Urogynecol J 18:503-511.

59. Timmons MC, Addison WA, Addison SB, Cavenar MG (1992). Abdominal sacral colpopexy in 163 women with posthysterectomy vaginal vault prolapse and enterocele. Evolution of operative techniques. J Reprod Med 37:323-327.

60. Vardy MD, Brodman M, Olivera CK, Zhou HS, Flisser AJ, Bercik RS (2007). Anterior intravaginal slingplasty tunneller device for stress incontinence and posterior intravaginal slingplasty for apical vault prolapse: a 2-year prospective multicenter study. Am J Obstet Gynecol 197:104-108.

61. Wu JM, Wells EC, Hundley AF, Connolly A, Williams KS, Visco AG (2006). Mesh erosion in abdominal sacral colpopexy with and without concomitant hysterectomy. Am J Obstet Gynecol 194:1418-1422. 
62. Brown M (2004). Long-term effectiveness of abdominal sacrocolpopexy for the treatment of pelvic organ prolapse. ClinicalTrials.gov Identifier NCT00099372. ClinicalTrials.gov [accessed September 2009] Available from: URL: http://clinicaltrials.gov/ct2/show/NCT00099372?term=nct00099372\&rank=1.

63. Chen CC (2007). Laparoscopic versus robotic assisted laparoscopic sacrocolpopexy for vaginal prolapse. ClinicalTrials.gov Identifier NCT00551993. ClinicalTrials.gov [accessed September 2009]. Available from: URL: http://clinicaltrials.gov/ct2/show/NCT00551993?term=nct00551993\&rank=1.

64. Culligan P (2005). Randomized controlled trial comparing acellular collagen biomesh (Pelvisoft) to polypropylene mesh (Pelvitex) for sacral colpopexy. ClinicalTrials.gov Identifier NCT00564083. ClinicalTrials.gov [accessed September 2009]. Available from: URL: http://clinicaltrials.gov/ct2/show/NCT00564083?term=nct00564083\&rank=1.

65. Freeman R (2006). LAS study - a randomised controlled trial of abdominal versus laparoscopic sacrocolpopexy for the treatment of post-hysterectomy vaginal vault prolapse. NRR ID N0185181850. National Research Register Archive [accessed September 2009]. Available from: URL: https://portal.nihr.ac.uk/Profiles/NRR.aspx?Publication_ID=N0185181850.

66. Gannon NA (2005). Treatment of stress and mixed urinary incontinence and vaginal vault prolapse. ClinicalTrials.gov Identifier NCT00223106. ClinicalTrials.gov [September 2009]. Available from: URL: http://clinicaltrials.gov/ct2/show/NCT00223106?term=nct00223106\&rank=1.

67. Halaska M (2007). Randomized multicentric study to treat prolapse after hysterectomy with Amreich procedure or total Prolift procedure. ClinicalTrials.gov Identifier 
NCT00572702. ClinicalTrials.gov [accessed September 2009]. Available from: URL: http://clinicaltrials.gov/ct2/show/NCT00572702?term=nct00572702\&rank=1.

68. Zylstra S (2006). Observational data collection of surgical outcomes in the treatment of vaginal prolapse with AMS products. ClincialTrials.gov Identifier NCT00388947. ClinicalTrials.gov [accessed September 2009]. Available from: URL: http://clinicaltrials.gov/ct2/show/NCT00388947?term=nct00388947\&rank=1.

69. Olsen AL, Smith VJ, Bergstrom JO, Colling JC, Clark AL (1997). Epidemiology of surgically managed pelvic organ prolapse and urinary incontinence. Obstet Gynecol 89:501-506.

70. National Institute for Health and Clinical Excellence (2009). Sacrocolpopexy using mesh for vaginal vault. Interventional Procedure Guidance IPG283. National Institute for Health and Clinical Excellence, London [accessed September 2009]. Available from: URL: http://www.nice.org.uk/nicemedia/pdf/IPG283Guidance.pdf.

71. National Institute for Health and Clinical Excellence (2009). Infracoccygeal sacropexy using mesh for uterine prolapse repair. Interventional Procedure Guidance IPG280. National Institute for Health and Clinical Excellence, London [accessed September 2009]. Available from: URL: http://www.nice.org.uk/nicemedia/pdf/IPG280Guidance.pdf.

72. National Institute for Health and Clinical Excellence (2009). Insertion of mesh uterine suspension sling (including sacrohysteropexy) for uterine prolapse repair. Interventional Procedure Guidance IPG282. National Institute for Health and Clinical Excellence, London [accessed September 2009]. Available from: URL:

http://www.nice.org.uk/nicemedia/pdf/IPG282guidance.pdf. 
73. National Institute for Health and Clinical Excellence (2009). Infracoccygeal sacropexy using mesh for vaginal vault prolapse repair. Interventional Procedure Guidance IPG281. National Institute for Health and Clinical Excellence, London [accessed September 2009]. Available from: URL: http://www.nice.org.uk/nicemedia/pdf/IPG281Guidance.pdf.

74. National Institute for Health and Clinical Excellence (2009). Sacrocolpopexy with hysterectomy using mesh for uterine prolapse repair. Interventional Procedure Guidance IPG284. National Institute for Health and Clinical Excellence, London [accessed September 2009]. Available from: URL:

http://www.nice.org.uk/nicemedia/pdf/IPG\%20284\%20Guidance\%20LR\%20FINAL.PDF.p df. 
Figure 1 Flow diagram for screening process.

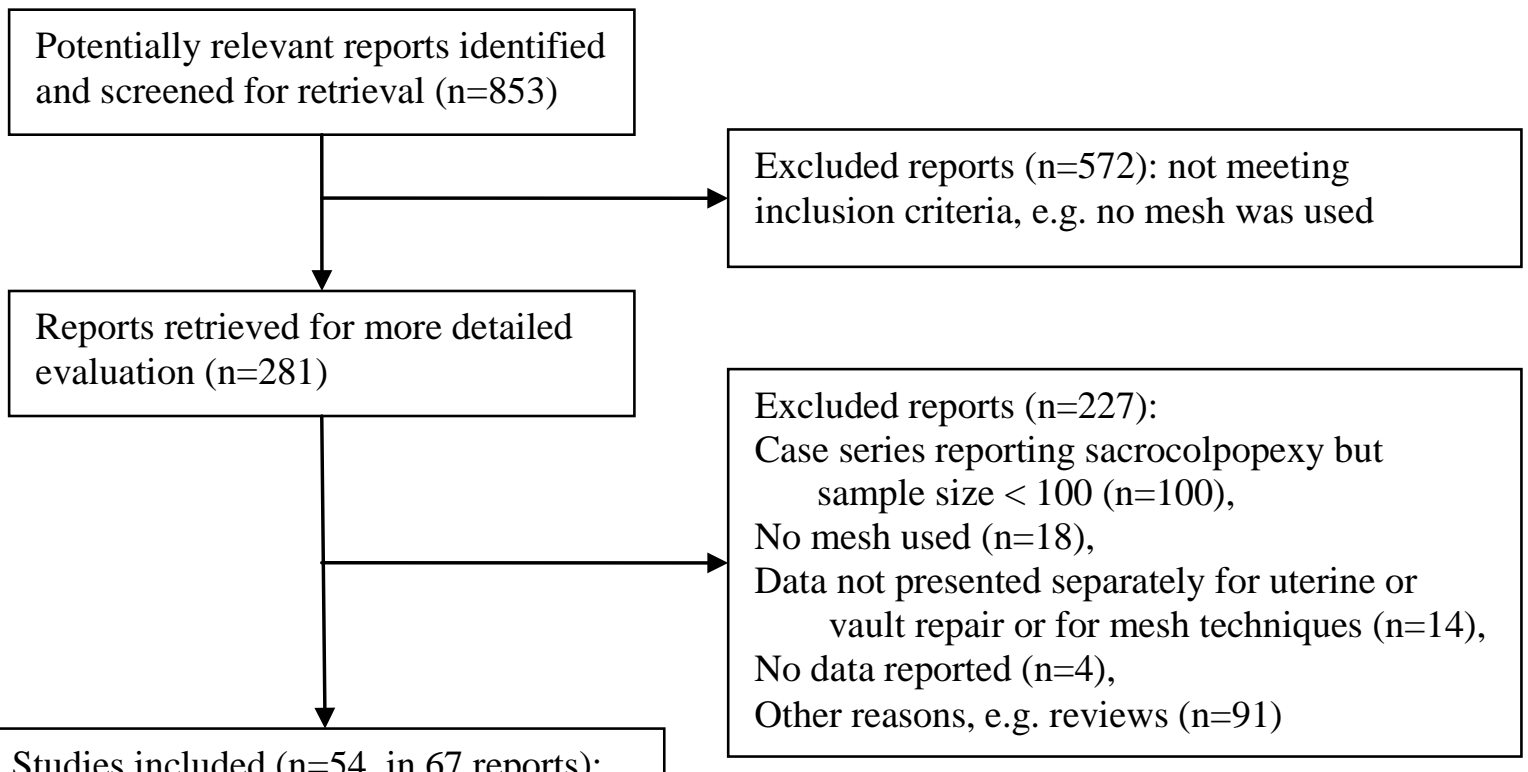

Studies included ( $\mathrm{n}=54$, in 67 reports):

5 full text RCTs,

3 RCTs available as conference abstract,

17 non-randomised comparative studies,

29 case series 
Table 1Median and ranges of event rates for primary efficacy and safety outcomes for sacrocolpopexy

\begin{tabular}{|c|c|c|c|c|c|c|c|c|c|}
\hline & \multicolumn{3}{|c|}{ Uterine } & \multicolumn{3}{|c|}{ Vault } & \multicolumn{3}{|c|}{ Uterine and/or vault } \\
\hline & No. study & $\mathbf{n} / \mathbf{N}, \%$ & Median (range) & No. study & $\mathrm{n} / \mathrm{N}, \%$ & Median (range) & No. study & $\mathbf{n} / \mathbf{N}, \%$ & Median (range) \\
\hline \multicolumn{10}{|c|}{ Patient reported persistent prolapse symptoms } \\
\hline RCT & 0 & & & 1 & $3 / 46(6.5 \%)$ & $6.5 \%$ & 1 & $6 / 38(16 \%)$ & $16 \%$ \\
\hline RCT (abs.) & 0 & & & 0 & & & 0 & & \\
\hline Non-rand & 0 & & & 1 & $13 / 60(22 \%)$ & $22 \%$ & $2^{\mathrm{a}}$ & $11 / 97(11 \%)$ & $14 \%(3.3-24)$ \\
\hline Case series & 0 & & & 1 & $22 / 103(21 \%)$ & $21 \%$ & 3 & 77/294 (26\%) & $26 \%(23-31)$ \\
\hline Total & \multicolumn{9}{|c|}{ Median 2.2\% (range 3-31), based on 9 studies (638 women) } \\
\hline \multicolumn{10}{|c|}{ Clinician reported recurrent prolapse at original site } \\
\hline RCT & 0 & & & $2^{\mathrm{a}}$ & $2 / 135(1.5 \%)$ & $2.2 \%(0-4.3)$ & 1 & $0 / 52(0 \%)$ & $0 \%$ \\
\hline RCT (abs.) & 1 & $0 / 23(0 \%)$ & $0 \%$ & 0 & & & 0 & & \\
\hline Non-rand & 1 & $0 / 39(0 \%)$ & $0 \%$ & $2^{\mathrm{a}}$ & 2/105 (1.9\%) & $2.2 \%(0-4.4)$ & 2 & $4 / 140(2.9 \%)$ & $3.1 \%(1.3-5.0)$ \\
\hline Case series & 0 & & & 1 & $4 / 66(6.1 \%)$ & $6.1 \%$ & 4 & $8 / 494(1.6 \%)$ & $1.8 \%(0-3.1)$ \\
\hline Total & \multicolumn{9}{|c|}{ Median 1.2\% (range 0-6.1), based on 14 studies (1054 women) } \\
\hline \multicolumn{10}{|c|}{ Mesh erosion } \\
\hline RCT & 0 & & & $2^{\mathrm{a}}$ & $3 / 147(2.0 \%)$ & $2.1 \%(2.0-2.1)$ & 0 & & \\
\hline RCT (abs.) & 1 & $1 / 23(4.3 \%)$ & $4.3 \%$ & 0 & & & 0 & & \\
\hline Non-rand & $2^{\mathrm{a}}$ & $12 / 143(8.4 \%)$ & $8.2 \%(7.7-8.7)$ & $2^{\mathrm{b}}$ & $7 / 162(4.3 \%)$ & $5.7 \%(2.6-8.9)$ & $8^{\mathrm{c}}$ & $22 / 577(3.8 \%)$ & $2.4 \%(0-12)$ \\
\hline Case series & 1 & $7 / 101(6.9 \%)$ & $6.9 \%$ & 4 & $35 / 660(5.3 \%)$ & $6.5 \%(0-8.7)$ & 7 & $31 / 1109(2.8 \%)$ & $2.4 \%(1.0-6.5)$ \\
\hline Total & \multicolumn{9}{|c|}{ Median 5.4\% (range 0-12), based on 27 studies (2922 women) } \\
\hline
\end{tabular}

a,b.c Results from the two arms of one/two/four studies were combined 
Table 2 Median and ranges of mesh erosion rates for sacrocolpopexy ${ }^{\mathrm{a}, \mathrm{b}}$

\begin{tabular}{|c|c|c|c|}
\hline & No. study & $\mathbf{n} / \mathbf{N}(\%)$ & Median (range) \\
\hline \multicolumn{4}{|c|}{ Non-absorbable synthetic mesh } \\
\hline Uterine & 3 & $19 / 280(6.8 \%)$ & $6.9 \%(4.0-8.7)$ \\
\hline Vault & 7 & $42 / 806(5.2 \%)$ & $4.7 \%(0-8.9)$ \\
\hline Uterine and/or vault & 11 & $26 / 783(3.3 \%)$ & $5.0 \%(0-12.0)$ \\
\hline Total & 21 & $87 / 1869(4.7 \%)$ & $4.0 \%(0-12)$ \\
\hline \multicolumn{4}{|c|}{ Absorbable synthetic mesh (no study reported data on this) } \\
\hline \multicolumn{4}{|c|}{ Absorbable biological graft } \\
\hline Uterine & 0 & & \\
\hline Vault & 1 & $0 / 46(0 \%)$ & $0 \%$ \\
\hline Uterine and/or vault & 4 & $1 / 183(0.5 \%)$ & $0 \%(0-0.8 \%)$ \\
\hline Total & 5 & $1 / 229(0.4 \%)$ & $0 \%(0-0.8)$ \\
\hline \multicolumn{4}{|c|}{ Combined (contain both non-absorbable and absorbable material) } \\
\hline Uterine & 1 & $1 / 23(4.3 \%)$ & $4.3 \%$ \\
\hline Vault & 0 & & \\
\hline Uterine and/or vault & 0 & & \\
\hline Total & 1 & $1 / 23(4.3 \%)$ & $4.3 \%$ \\
\hline
\end{tabular}

${ }^{\mathrm{a}}$ Four studies reported two different types of mesh separately.

${ }^{b}$ Five studies (5/27, $18.5 \%$ ) that reported data on mesh erosion were not included in this table because they either did not report type of mesh used or used a mixture of different types but not reported them separately. 


\begin{tabular}{|c|c|c|c|}
\hline & \multicolumn{3}{|c|}{$\begin{array}{c}\text { Sacrocolpoperineopexy } \\
\text { (not reported separately by uterine and vault) }\end{array}$} \\
\hline & No. study & $\mathbf{n} / \mathbf{N}, \%$ & Median (range) \\
\hline \multicolumn{4}{|c|}{ Patient reported persistent prolapse symptoms } \\
\hline RCT & 0 & & \\
\hline RCT (abstract) & 0 & & \\
\hline Non-randomised comparative studies & 0 & & \\
\hline Case series & 1 & $2 / 169(1.2 \%)$ & $1.2 \%$ \\
\hline Total & \multicolumn{3}{|c|}{ Median 1.2\%, based on 1 study (169 women) } \\
\hline \multicolumn{4}{|c|}{ Clinician reported recurrent prolapse at original site } \\
\hline RCT & 0 & & \\
\hline RCT (abstract) & 0 & & \\
\hline Non-randomised comparative studies & 0 & & \\
\hline Case series & 1 & $1 / 169(0.6 \%)$ & $0.6 \%$ \\
\hline Total & \multicolumn{3}{|c|}{ Median $0.6 \%$, based on 1 study (169 women) } \\
\hline \multicolumn{4}{|l|}{ Mesh erosion } \\
\hline RCT & 0 & & \\
\hline RCT (abstract) & 0 & & \\
\hline Non-randomised comparative studies & 1 & $10 / 118(8.5 \%)$ & $8.5 \%$ \\
\hline Case series & 1 & $14 / 169(8.3 \%)$ & $8.3 \%$ \\
\hline Total & \multicolumn{3}{|c|}{ Median 8.4\% (range 8.3-8.5), based on 2 studies ( 287 women) } \\
\hline
\end{tabular}


Table 4 Median and ranges of event rates for primary efficacy and safety outcomes for infracoccygeal sacropexy

\begin{tabular}{|c|c|c|c|c|c|c|c|c|c|}
\hline & \multicolumn{3}{|c|}{ Uterine } & \multicolumn{3}{|c|}{ Vault } & \multicolumn{3}{|c|}{ Uterine and/or vault } \\
\hline & No. study & $\mathbf{n} / \mathbf{N}, \%$ & Median (range) & No. study & $\mathbf{n} / \mathbf{N}, \%$ & Median (range) & No. study & $\mathbf{n} / \mathbf{N}, \%$ & Median (range) \\
\hline \multicolumn{10}{|c|}{ Patient reported persistent prolapse symptoms } \\
\hline RCT & 0 & & & 0 & & & 0 & & \\
\hline RCT (abs.) & 0 & & & 0 & & & 0 & & \\
\hline Non-rand & 0 & & & 0 & & & 0 & & \\
\hline Case series & 0 & & & 1 & 8/91 (8.8\%) & $8.8 \%$ & 2 & 28/171 (16\%) & $12 \%(2.3-21)$ \\
\hline Total & \multicolumn{9}{|c|}{ Median 8.8\% (range 2-21), based on 3 studies (262 women) } \\
\hline \multicolumn{10}{|c|}{ Clinician reported recurrent prolapse at original site } \\
\hline RCT & 0 & & & 0 & & & 0 & & \\
\hline RCT (abs.) & 0 & & & 0 & & & 1 & $1 / 21(4.8 \%)$ & $4.8 \%$ \\
\hline Non-rand & $1^{\mathrm{a}}$ & $1 / 79(1.3 \%)$ & $1.3 \%$ & 0 & & & 0 & & \\
\hline Case series & 1 & $1 / 10(10 \%)$ & $10 \%$ & 2 & $4 / 60(6.7 \%)$ & $5.0 \%(0-10)$ & 4 & $17 / 232(7.3 \%)$ & $6.5 \%(0-25)$ \\
\hline Total & \multicolumn{9}{|c|}{ Median $4.8 \%$ (range $0-25)$, based on 9 studies (402 women) } \\
\hline \multicolumn{10}{|c|}{ Mesh erosion } \\
\hline RCT & 0 & & & 0 & & & 0 & & \\
\hline RCT (abs.) & 0 & & & 1 & $2 / 30(6.7 \%)$ & $6.7 \%$ & 1 & $0 / 21(0 \%)$ & $0 \%$ \\
\hline Non-rand & $1^{\mathrm{a}}$ & $10 / 79(13 \%)$ & $13 \%$ & 0 & & & 0 & & \\
\hline Case series & 0 & & & 4 & $22 / 235(9.4 \%)$ & $6.6 \%(5.3-21 \%)$ & 4 & $33 / 524(6.3 \%)$ & $5.6 \%(1.5-17)$ \\
\hline Total & \multicolumn{9}{|c|}{ Median 6.7\% (range 0-21), based on 11 studies (889 women) } \\
\hline
\end{tabular}

${ }^{\text {a }}$ Results from the two arms of one study were combined 


\begin{tabular}{|c|c|c|c|}
\hline & \multicolumn{3}{|c|}{$\begin{array}{c}\text { Uterine suspension sling } \\
\text { (for uterine prolapsed only) }\end{array}$} \\
\hline & No. study & $\mathbf{n} / \mathbf{N}, \%$ & Median (range) \\
\hline \multicolumn{4}{|c|}{ Patient reported persistent prolapse symptoms } \\
\hline RCT & 1 & $16 / 41(39 \%)$ & $39 \%$ \\
\hline RCT (abstract) & 0 & & \\
\hline Non-randomised comparative studies & 0 & & \\
\hline Case series & 2 & $1 / 50(2.0 \%)$ & $1.6 \%(0-3.3)$ \\
\hline Total & \multicolumn{3}{|c|}{ Median 3.3\% (range 0-39), based on 3 studies (91 women) } \\
\hline \multicolumn{4}{|c|}{ Clinician reported recurrent prolapse at original site } \\
\hline RCT & 1 & $2 / 38(5.3 \%)$ & $5.3 \%$ \\
\hline RCT (abstract) & 0 & & \\
\hline Non-randomised comparative studies & 1 & $0 / 36(0 \%)$ & $0 \%$ \\
\hline Case series & 3 & $2 / 62(3.2 \%)$ & $3.3 \%(0-7.7)$ \\
\hline Total & \multicolumn{3}{|c|}{ Median 3.3\% (range 0-7.7), based on 5 studies (136 women) } \\
\hline \multicolumn{4}{|l|}{ Mesh erosion } \\
\hline RCT & 0 & & \\
\hline RCT (abstract) & 0 & & \\
\hline Non-randomised comparative studies & 1 & $0 / 36(0 \%)$ & 0 \\
\hline Case series & 1 & $1 / 30(3.3 \%)$ & $3.3 \%$ \\
\hline Total & \multicolumn{3}{|c|}{ Median 1.7\% (range 0-3.3), based on 2 studies (66 women) } \\
\hline
\end{tabular}




\begin{tabular}{|c|c|c|c|c|c|c|c|c|c|c|}
\hline ID & $\mathbf{N}$ & Age, $y$ & $\begin{array}{l}\text { Uterine/ } \\
\text { vault }\end{array}$ & $\begin{array}{l}\text { Primary/ } \\
\text { secondary }\end{array}$ & Intervention route & Technique & Mesh/graft, trade name & $\begin{array}{l}\text { Concomitant } \\
\text { procedure }\end{array}$ & Follow up, mean & Outcomes \\
\hline \multicolumn{11}{|l|}{ UTERINE } \\
\hline \multicolumn{11}{|l|}{ RCT (abs.) } \\
\hline Braun 2007[13] & $\begin{array}{l}\text { A, } 23 \\
\text { B, } 24\end{array}$ & $\begin{array}{l}\text { A, } 57 \\
\text { B, } 56\end{array}$ & $\begin{array}{l}\text { A, } 23 / 0 \\
\text { B, } 24 / 0\end{array}$ & NR & $\begin{array}{l}\text { A, abdominal } \\
\text { B, vaginal }\end{array}$ & $\begin{array}{l}\text { A, hysterectomy + sacrocolpopexy; } \\
\text { B, hysterectomy + anteroposterior } \\
\text { colporrhaphy + Mayo McCall stitch }\end{array}$ & $\begin{array}{l}\text { A, combined mesh, polyglactin } \\
\text { and prolene } 1: 1 \text {, Vypro } \\
\text { B, no mesh }\end{array}$ & NR & 33m (20-41) & $\begin{array}{l}\text { Efficacy } \\
\text { Safety }\end{array}$ \\
\hline \multicolumn{11}{|c|}{ Non-randomised comparative studies } \\
\hline $\begin{array}{l}\text { Costantini } \\
\text { 2005[19] }\end{array}$ & $\begin{array}{l}\text { A, } 36 \\
\text { B, } 39\end{array}$ & $\begin{array}{l}\text { A, } 61(12) \\
\text { B, } 62(8)\end{array}$ & $\begin{array}{l}\text { A, } 36 / 0 \\
\text { B, } 39 / 0\end{array}$ & NR & $\begin{array}{l}\text { A, abdominal } \\
\text { B, abdominal }\end{array}$ & $\begin{array}{l}\text { A, sacrohysteropexy } \\
\text { B, hysterectomy + sacrocolpopexy }\end{array}$ & $\begin{array}{l}\text { A, polypropylene, Marlex } \\
\text { (Amid type I) } \\
\text { B, same as A }\end{array}$ & $\begin{array}{l}\text { Anti-incontinence: } \\
\text { A, 28/36; B, 30/39 } \\
\text { Hysterectomy: } \\
\text { A, 0/36; B, 39/39 }\end{array}$ & 51m (12-115) & $\begin{array}{l}\text { Efficacy } \\
\text { Safety }\end{array}$ \\
\hline Griffis 2006[23] & $\begin{array}{l}\text { A, } 60 \\
\text { B, } 28\end{array}$ & NR & $\begin{array}{l}\text { A, } 60 / 0 \\
\text { B, } 28 / 0\end{array}$ & NR & $\begin{array}{l}\text { A, abdominal } \\
\text { B, abdominal }\end{array}$ & $\begin{array}{l}\text { A, total hysterectomy + sacrocolpopexy } \\
\text { B, supracervical hysterectomy + } \\
\text { sacrocolpopexy }\end{array}$ & $\begin{array}{l}\text { A, polypropylene, Prolene soft, } \\
\text { Prolene (Amid type I), or } \\
\text { Atrium (NR Amid type); } \\
\text { polyethylene tetraphalate, } \\
\text { Mersilene (Amid type III) } \\
\text { B, same as A }\end{array}$ & NR & 13m (12-15) & Safety \\
\hline $\begin{array}{l}\text { Case series } \\
\text { Wu 2006[61] }\end{array}$ & 101 & $64(12)$ & $101 / 0$ & $101 / 0$ & Abdominal (open) & Hysterectomy + sacrocolpopexy & $\begin{array}{l}\text { polyethylene tetraphalate, } \\
\text { Mersilene (Amid type III); } \\
\text { polypropylene (NR trade name); } \\
\text { or Gore-Tex (Amid type II) }\end{array}$ & NR & $15 \mathrm{~m}(0.2-120)$ & Safety \\
\hline & & & & & & & & & & \\
\hline Culligan 2005[9] & $\begin{array}{l}\text { A, } 54 \\
\text { B, } 46\end{array}$ & $\begin{array}{l}\text { A, } 60(10) \\
\text { B, } 58(11)\end{array}$ & $\begin{array}{l}\text { A, } 0 / 54 \\
\text { B, } 0 / 46\end{array}$ & NR & $\begin{array}{l}\text { A, abdominal (open) } \\
\text { B, abdominal (open) }\end{array}$ & $\begin{array}{l}\text { A, sacrocolpopexy } \\
\text { B, sacrocolpopexy }\end{array}$ & $\begin{array}{l}\text { A, polypropylene, Trelex } \\
\text { B, cadaveric fascia lata, } \\
\text { Tutoplast }\end{array}$ & NR & $1 \mathrm{y}$ & $\begin{array}{l}\text { Efficacy } \\
\text { Safety }\end{array}$ \\
\hline Maher 2004[11] & $\begin{array}{l}\mathrm{A}, 47 \\
\mathrm{~B}, 48\end{array}$ & $\begin{array}{l}\text { A, } 63(39-84) \\
\text { B, } 63(35-88)\end{array}$ & $\begin{array}{l}\text { A, } 0 / 47 \\
\text { B, } 0 / 48\end{array}$ & NR & $\begin{array}{l}\text { A, abdominal } \\
\text { B, vaginal }\end{array}$ & $\begin{array}{l}\text { A, sacrocolpopexy } \\
\text { B, unilateral vaginal sacrospinous } \\
\text { colpopexy }\end{array}$ & $\begin{array}{l}\text { A, polypropylene, Prolene } \\
\text { (Amid type I) } \\
\text { B, no mesh }\end{array}$ & NR & $24 \mathrm{~m}(6-60)$ & $\begin{array}{l}\text { Efficacy } \\
\text { Safety }\end{array}$ \\
\hline \multicolumn{11}{|c|}{ Non-randomised comparative studies } \\
\hline Govier 2005[21] & $\begin{array}{l}\text { A, } 24 \\
\text { B, } 21\end{array}$ & $\begin{array}{l}\text { A+B, } 67(51- \\
86)\end{array}$ & $\begin{array}{l}\text { A, } 0 / 24 \\
\text { B, } 0 / 21\end{array}$ & NR & $\begin{array}{l}\text { A, abdominal (open or } \\
\text { laparoscopic) } \\
\text { B, abdominal (open or } \\
\text { laparoscopic) }\end{array}$ & $\begin{array}{l}\text { A, sacrocolpopexy } \\
\text { B, sacrocolpopexy }\end{array}$ & $\begin{array}{l}\text { A, polypropylene, Prolene } \\
\text { B, silicone-covered } \\
\text { polyethylene mesh, American } \\
\text { Medical Systems }\end{array}$ & $\mathrm{A}+\mathrm{B}, 20 / 45$ & $\begin{array}{l}\text { A, } 12 \mathrm{~m}(1-38) \\
\text { B, 23m (16-41) }\end{array}$ & $\begin{array}{l}\text { Efficacy } \\
\text { Safety }\end{array}$ \\
\hline $\begin{array}{l}\text { Marcickiewicz } \\
\text { 2007[26] }\end{array}$ & $\begin{array}{l}\text { A, } 60 \\
\text { B, } 51\end{array}$ & $\begin{array}{l}\text { A, } 58(30-83) \\
\text { B, } 66(43-88)\end{array}$ & $\begin{array}{l}\text { A, } 0 / 60 \\
\text { B, } 0 / 51\end{array}$ & NR & $\begin{array}{l}\text { A, abdominal } \\
\text { (laparoscopic) } \\
\text { B, vaginal }\end{array}$ & $\begin{array}{l}\text { A, sacrocolpopexy } \\
\text { B, sacrospinous colpopexy }\end{array}$ & $\begin{array}{l}\text { A, polypropylene, Prolene } \\
\text { B, no mesh }\end{array}$ & A, 6/60; B, 8/51 & $\begin{array}{l}\text { A, 34m (13-60) } \\
\text { B, 38m (7-108) }\end{array}$ & $\begin{array}{l}\text { Efficacy } \\
\text { Safety }\end{array}$ \\
\hline Paraiso 2005[29] & $\begin{array}{l}\text { A, } 56 \\
\text { B, } 61\end{array}$ & $\begin{array}{l}\text { A, } 62(39-85) \\
\text { B, } 61(35-81)\end{array}$ & $\begin{array}{l}\text { A, } 0 / 56 \\
\text { B, } 0 / 61\end{array}$ & NR & $\begin{array}{l}\text { A, abdominal } \\
\text { (laparoscopic) } \\
\text { B, abdominal (open) }\end{array}$ & $\begin{array}{l}\text { A, sacrocolpopexy } \\
\text { B, sacrocolpopexy }\end{array}$ & $\begin{array}{l}\text { A, cadaveric fascia lata, } \\
\text { Tutoplast, or polypropylene, } \\
\text { Prolene } \\
\text { B, save as above }\end{array}$ & A, 24/56; B, 38/61 & $\begin{array}{l}\text { A, } 14 \mathrm{~m}(1-46) \\
\text { B, 16m (1-73) }\end{array}$ & Safety \\
\hline
\end{tabular}




\begin{tabular}{|c|c|c|c|c|c|c|c|c|c|c|}
\hline$\overline{\text { ID }}$ & $\mathbf{N}$ & Age, $y$ & $\begin{array}{l}\text { Uterine/ } \\
\text { vault }\end{array}$ & $\begin{array}{l}\text { Primary/ } \\
\text { secondary }\end{array}$ & Intervention route & Technique & Mesh/graft, trade name & $\begin{array}{l}\text { Concomitant } \\
\text { procedure }\end{array}$ & Follow up, mean & Outcomes \\
\hline $\begin{array}{l}\text { Case series } \\
\text { Fedorkow } \\
1993[42]\end{array}$ & 149 & $58(11)$ & $0 / 149$ & NR & Abdominal & Sacrocolpopexy & $\begin{array}{l}\text { Polypropylene, Prolene (Amid } \\
\text { type I) }\end{array}$ & NR & NR & Safety \\
\hline Griffis 2006[23] & 196 & NR & $0 / 196$ & NR & Abdominal & Sacrocolpopexy & $\begin{array}{l}\text { Polypropylene, Prolene-Soft, } \\
\text { Prolene (Amid type I), or } \\
\text { Atrium (NR Amid type); } \\
\text { polyethylene tetraphalate, } \\
\text { Mersilene (Amid type III). }\end{array}$ & NR & $13 \mathrm{~m}$ & Safety \\
\hline Higgs 2005a[47] & 103 & $58(10)$ & $0 / 103$ & NR & $\begin{array}{l}\text { Abdominal } \\
\text { (laparoscopic) }\end{array}$ & Sacrocolpopexy & $\begin{array}{l}\text { Polypropylene, Prolene (Amid } \\
\text { type I) }\end{array}$ & $39 / 103$ & 66m (37-124) & $\begin{array}{l}\text { Efficacy } \\
\text { Safety }\end{array}$ \\
\hline Wu 2006[61] & 212 & $66(11)$ & $0 / 212$ & $212 / 0$ & Abdominal (open) & Sacrocolpopexy & $\begin{array}{l}\text { Polyethylene tetraphalate, } \\
\text { Mersilene (Amid type III); } \\
\text { polypropylene (NR trade } \\
\text { name); or Gore-Tex }\end{array}$ & NR & 15m (0.3-121) & Safety \\
\hline \multicolumn{11}{|c|}{ UTERINE AND/OR VAULT } \\
\hline $\begin{array}{l}\boldsymbol{R C T} \\
\text { Benson 1996[8] }\end{array}$ & $\begin{array}{l}\text { A, } 40 \\
\text { B, } 48\end{array}$ & $\begin{array}{l}\text { A, } 66(10) \\
\text { B, } 64(9)\end{array}$ & NR & NR & $\begin{array}{l}\text { A, abdominal } \\
\text { B, vaginal }\end{array}$ & $\begin{array}{l}\text { A, sacrocolpopexy } \\
\text { B, bilateral sacrospinous ligament vault } \\
\text { suspension }\end{array}$ & $\begin{array}{l}\text { A, NR } \\
\text { B, no mesh }\end{array}$ & $\begin{array}{l}\text { Anti-incontinence: } \\
\text { A, 14/40; B, 20/48 } \\
\text { Hysterectomy: } \\
\text { A, 20/40; B, 24/48 }\end{array}$ & $2.5 y(1-5.5)$ & $\begin{array}{l}\text { Efficacy } \\
\text { Safety }\end{array}$ \\
\hline Lo 1998[10] & $\begin{array}{l}\text { A, } 52 \\
\text { B, } 66\end{array}$ & $\begin{array}{l}\text { A, } 63(9) \\
\text { B, } 60(10)\end{array}$ & NR & NR & $\begin{array}{l}\text { A, abdominal (open) } \\
\text { B, vaginal }\end{array}$ & $\begin{array}{l}\text { A, sacrocolpopexy } \\
\text { B, sacrospinous ligament suspension }\end{array}$ & $\begin{array}{l}\text { A, polyethylene tetraphalate, } \\
\text { Mersilene (Amid type III) } \\
\text { B, no mesh }\end{array}$ & $\begin{array}{l}\text { Anti-incontinence: } \\
\text { A, 0/52; B, 0/66 } \\
\text { Hysterectomy: } \\
\text { A, 33/52; B, 20/66 } \\
\end{array}$ & $2.1 \mathrm{y}(1-5.2)$ & $\begin{array}{l}\text { Efficacy } \\
\text { Safety }\end{array}$ \\
\hline $\begin{array}{l}\text { Non-randomised } \\
\text { Altman 2005[16] }\end{array}$ & $\begin{array}{l}\text { comparc } \\
\text { A, } 25 \\
\text { B, } 27\end{array}$ & $\begin{array}{l}\text { e studies } \\
\text { A, } 66 \text { (54-83) } \\
\text { B, } 69(55-84)\end{array}$ & NR & NR & $\begin{array}{l}\text { A, abdominal } \\
\text { B, abdominal }\end{array}$ & $\begin{array}{l}\text { A, sacrocolpopexy } \\
\text { B, sacrocolpopexy }\end{array}$ & $\begin{array}{l}\text { A, } 12 \text { polypropylene, } 13 \\
\text { polytetrafluoroethylene (NR } \\
\text { trade name) } \\
\text { B, porcine dermis, Pelvicol }\end{array}$ & $\begin{array}{l}\text { Hysterectomy: } \\
\text { A, 2/25; B, 5/27 }\end{array}$ & $\begin{array}{l}\text { Efficacy } \\
\text { A, 7.4m; B, 7.1m } \\
\text { Safety } \\
\text { A, 4.3y; B, 2.5y }\end{array}$ & Safety \\
\hline Bai 2006[17] & $\begin{array}{l}\text { A, } 20 \\
\text { B, } 54\end{array}$ & NR & NR & NR & $\begin{array}{l}\text { A, abdominal } \\
\text { B, abdominal }\end{array}$ & $\begin{array}{l}\text { A, sacrocolpopexy } \\
\text { B, high uterosacral colpopexy }\end{array}$ & $\begin{array}{l}\text { A, polyethylene tetraphalate, } \\
\text { Mersilene (Amid type III) } \\
\text { B, no mesh }\end{array}$ & $\begin{array}{l}\text { Performed if needed } \\
\text { but NR numbers. }\end{array}$ & $1 y$ & Safety \\
\hline Begley 2005[18] & $\begin{array}{l}\text { A, } 24 \\
\text { B, } 33 \\
\text { C, } 21 \\
\text { D, } 14\end{array}$ & $\begin{array}{l}\text { A, } 69(49-86) \\
\text { B, } 66(37-84) \\
\text { C, } 66(40-85) \\
\text { D, } 63(25-83)\end{array}$ & NR & $\mathrm{A}+\mathrm{B}, 85 / 7$ & $\begin{array}{l}\text { A, abdominal (19 } \\
\text { open, } 5 \text { laparoscopic) } \\
\text { B, abdominal (open) } \\
\text { C, abdominal (18 } \\
\text { open, } 3 \text { laparoscopic) } \\
\text { D, abdominal (open) }\end{array}$ & $\begin{array}{l}\text { A, sacrocolpopexy } \\
\text { B, sacrocolpopexy } \\
\text { C, sacrocolpopexy } \\
\text { D, sacrocolpopexy }\end{array}$ & $\begin{array}{l}\text { A, polypropylene, Marlex or } \\
\text { Prolene (Amid type I) } \\
\text { B, polypropylene, Gore-Tex } \\
\text { (Amid type II) } \\
\text { C, silicon-covered polyester, } \\
\text { American Medical Systems } \\
\text { D, } 1 \text { autologous and } 13 \\
\text { cadaveric fascia lata, Tutoplast }\end{array}$ & $\begin{array}{l}\text { Anti-incontinence: } \\
\text { A, 9/24; B, 14/33; } \\
\text { C, 9/21; D, 5/14 } \\
\text { Hysterectomy: } \\
\text { A, 1/24; B, 8/33; C, } \\
\text { 3/21; D, 7/14 }\end{array}$ & $\begin{array}{l}\text { A, } 10 \mathrm{~m} \\
\text { B, } 29 \mathrm{~m} \\
\text { C, } 16 \mathrm{~m} \\
\mathrm{D}, 19 \mathrm{~m}\end{array}$ & $\begin{array}{l}\text { Efficacy } \\
\text { Safety }\end{array}$ \\
\hline
\end{tabular}




\begin{tabular}{|c|c|c|c|c|c|c|c|c|c|c|}
\hline ID & $\mathbf{N}$ & Age, $y$ & $\begin{array}{l}\text { Uterine/ } \\
\text { vault }\end{array}$ & $\begin{array}{l}\text { Primary/ } \\
\text { secondary }\end{array}$ & Intervention route & Technique & Mesh/graft, trade name & $\begin{array}{l}\text { Concomitant } \\
\text { procedure }\end{array}$ & Follow up, mean & Outcomes \\
\hline $\begin{array}{l}\text { Gregory } \\
2005[22]\end{array}$ & $\begin{array}{l}\text { A, } 49 \\
\text { B, } 33\end{array}$ & NR & NR & NR & $\begin{array}{l}\text { A, abdominal (open) } \\
\text { B, abdominal (open) }\end{array}$ & $\begin{array}{l}\text { A, sacrocolpopexy } \\
\text { B, sacrocolpopexy }\end{array}$ & $\begin{array}{l}\text { A, polypropylene, Marlex } \\
\text { (Amid type I); polyethylene } \\
\text { tetraphalate, Mersilene (Amid } \\
\text { type II) } \\
\text { B, fascia lata, Community } \\
\text { Tissue Services }\end{array}$ & $\begin{array}{l}\text { Performed but NR } \\
\text { numbers }\end{array}$ & $\begin{array}{l}\text { A, } 26(10-48) \\
\text { B, } 21(11-34)\end{array}$ & $\begin{array}{l}\text { Efficacy } \\
\text { Safety }\end{array}$ \\
\hline $\begin{array}{l}\text { Hardiman } \\
1996[24]\end{array}$ & $\begin{array}{l}\text { A, } 80 \\
\text { B, } 125\end{array}$ & $\begin{array}{l}\text { A, } 61 \\
\text { B, } 64\end{array}$ & NR & NR & $\begin{array}{l}\text { A, abdominal } \\
\text { B, vaginal }\end{array}$ & $\begin{array}{l}\text { A, sacrocolpopexy } \\
\text { B, sacrospinous vault suspension }\end{array}$ & $\begin{array}{l}\text { A, polypropylene, Marlex } \\
\text { (Amid type I) } \\
\text { B, no mesh }\end{array}$ & $\begin{array}{l}\text { Anti-incontinence: } \\
\text { A, 76/80; B, 45/125 } \\
\text { Hysterectomy: } \\
\text { A, 18/80; B, 45/125 }\end{array}$ & $\begin{array}{l}\text { A, } 3.9 y \\
B, 2.2 y \\
A+B, 6 m-5 y\end{array}$ & $\begin{array}{l}\text { Efficacy } \\
\text { Safety }\end{array}$ \\
\hline Hsiao 2007[25] & $\begin{array}{l}\text { A, } 25 \\
\text { B, } 22\end{array}$ & $\begin{array}{l}\text { A, } 66 \\
\text { B, } 71\end{array}$ & $\begin{array}{l}\text { A, } 2 / 23 \\
\text { B, } 3 / 19\end{array}$ & NR & $\begin{array}{l}\text { A, abdominal } \\
\text { (laparoscopic) } \\
\text { B, abdominal (open) }\end{array}$ & $\begin{array}{l}\text { A, sacrocolpopexy } \\
\text { B, sacrocolpopexy }\end{array}$ & $\begin{array}{l}\text { A, } 19 \text { polypropylene, Prolene; } \\
3 \text { silicone mesh } \\
\text { B, } 2 \text { fascia lata; } 13 \\
\text { polypropylene, Prolene; } 5 \\
\text { silicon mesh; } 2 \text { polypropylene, } \\
\text { Gore-Tex }\end{array}$ & $\begin{array}{l}\text { Anti-incontinence: } \\
\text { A, 9/25; B, 10/22 } \\
\text { Hysterectomy: } \\
\text { NR }\end{array}$ & $\begin{array}{l}\text { A, } 6 \mathrm{~m} \\
\text { B, } 10 \mathrm{~m}\end{array}$ & Safety \\
\hline Ng 2004[28] & $\begin{array}{l}\text { A, } 113 \\
\text { B, } 64\end{array}$ & $\begin{array}{l}\text { A, } 60 \\
\text { B, } 63\end{array}$ & $\begin{array}{l}\text { A, } 78 / 35 \\
\text { B, 37/27 }\end{array}$ & NR & $\begin{array}{l}\text { A, abdominal (open) } \\
\text { B, vaginal }\end{array}$ & $\begin{array}{l}\text { A, sacrocolpopexy } \\
\text { B, sacrospinous ligament fixation }\end{array}$ & $\begin{array}{l}\text { A, polytetrafluoroethylene, } \\
\text { Gore-Tex (Amid type II) } \\
\text { B, no mesh }\end{array}$ & $\begin{array}{l}\text { Anti-incontinence: } \\
\text { A, 28/113; B, 12/64 } \\
\text { Hysterectomy: } \\
\text { A, 78/113; B, 38/64 }\end{array}$ & $\begin{array}{l}\text { A, } 18 m(1-48) \\
\text { B, 13m (1-29) }\end{array}$ & $\begin{array}{l}\text { Efficacy } \\
\text { Safety }\end{array}$ \\
\hline Sze 1999[30] & $\begin{array}{l}\text { A, } 56 \\
\text { B, } 61\end{array}$ & $\begin{array}{l}\text { A, } 57(34-74) \\
\text { B, } 64(43-76)\end{array}$ & $\begin{array}{l}\text { A, } 19 / 35 \\
\text { B, } 7 / 40\end{array}$ & NR & $\begin{array}{l}\text { A, abdominal (open) } \\
\text { B, vaginal }\end{array}$ & $\begin{array}{l}\text { A, sacrocolpopexy } \\
\text { B, sacrospinous ligament fixation }\end{array}$ & $\begin{array}{l}\text { A, NR } \\
\text { B, no mesh }\end{array}$ & $\begin{array}{l}\text { Anti-incontinence: } \\
\text { A, 56/56; B, 61/61 } \\
\text { Hysterectomy: } \\
\text { A, 7/56; B, 19/61 }\end{array}$ & $\begin{array}{l}\text { A, 23m (4-51) } \\
\text { B, 24m (7-72) }\end{array}$ & Safety \\
\hline Visco 2001[31] & $\begin{array}{l}\text { A, } 155 \\
\text { B, } 88 \\
\text { C, } 25 \\
\text { D, } 5\end{array}$ & $\begin{array}{l}A+B+C+D, 61 \\
(31-84)\end{array}$ & NR & NR & $\begin{array}{l}\text { A, abdominal } \\
\text { B, abdominal } \\
\text { C, vaginal+ abdominal } \\
\text { D, vaginal+ abdominal }\end{array}$ & $\begin{array}{l}\text { A, sacrocolpopexy } \\
\text { B, sacrocolpoperineopexy } \\
\text { C, sacrocolpoperineopexy } \\
\text { D, sacrocolpoperineopexy with mesh } \\
\text { placed to vaginal field }\end{array}$ & $\begin{array}{l}\text { A, polyethylene tetraphalate, } \\
\text { Mersilene (Amid type III) or } \\
\text { Gore-Tex (Amid type II) } \\
\text { B, C, D, same as above }\end{array}$ & $\begin{array}{l}\text { Anti-incontinence: } \\
\text { NR } \\
\text { Hysterectomy: } \\
\text { A+B+C+D: 45/273 }\end{array}$ & $\begin{array}{l}\text { A, } 7 \mathrm{~m}(1-87) \\
\text { B, } 5(1-45) \\
\text { C, } 6 \mathrm{~m}(1-28) \\
\text { D, } 7 \mathrm{~m}(2-11)\end{array}$ & \\
\hline $\begin{array}{l}\text { Young 2004[32] } \\
\text { (prospective } \\
\text { registry) }\end{array}$ & $\begin{array}{l}\text { A, } 92 \\
\text { B, } 187 \\
\text { C, } 70\end{array}$ & $\begin{array}{l}\text { A, } 61(28-84) \\
\text { B, } 37-87 \\
\text { C, } 64(34-84)\end{array}$ & NR & NR & $\begin{array}{l}\text { A, abdominal } \\
\text { (laparoscopic) } \\
\text { B, vaginal } \\
\text { C, vaginal }\end{array}$ & $\begin{array}{l}\text { A, sacrocolpopexy } \\
\text { B, sacrospinous fixation } \\
\text { C, high uterosacral suspension }\end{array}$ & $\begin{array}{l}\text { A, a mixture of biological } \\
\text { grafts and non-absorbable } \\
\text { synthetic mesh } \\
\text { B, no mesh } \\
\text { C, no mesh }\end{array}$ & $\begin{array}{l}\text { Anti-incontinence: } \\
\text { A, 44/92; B, 28/187; } \\
\text { C, 8/70 } \\
\text { Hysterectomy: } \\
\text { A, 6/92; B, 63/187; C, } \\
\text { 17/70 }\end{array}$ & $\begin{array}{l}\text { NR, a safety } \\
\text { registry in a year } \\
\text { (Oct. 1998-Oct. } \\
\text { 1999) }\end{array}$ & Safety \\
\hline $\begin{array}{l}\text { Case series } \\
\text { Bensinger } \\
\text { 2005[35] }\end{array}$ & 121 & $53(10)$ & $86 / 35$ & $121 / 0$ & Abdominal & Sacrocolpopexy & $\begin{array}{l}\text { Polypropylene (NR trade } \\
\text { name) }\end{array}$ & $\begin{array}{l}\text { Anti-incontinence: } \\
\text { 82/121 } \\
\text { Hysterectomy: NR }\end{array}$ & $13 \mathrm{~m}(0.3-63)$ & Safety \\
\hline
\end{tabular}




\begin{tabular}{|c|c|c|c|c|c|c|c|c|c|c|}
\hline ID & $\mathbf{N}$ & Age, $y$ & $\begin{array}{l}\text { Uterine/ } \\
\text { vault }\end{array}$ & $\begin{array}{l}\text { Primary/ } \\
\text { secondary }\end{array}$ & Intervention route & Technique & Mesh/graft, trade name & $\begin{array}{l}\text { Concomitant } \\
\text { procedure }\end{array}$ & Follow up, mean & Outcomes \\
\hline $\begin{array}{l}\text { Brizzolara } \\
\text { 2003[37] }\end{array}$ & 124 & $65(9)$ & $60 / 64$ & NR & Abdominal & Sacrocolpopexy & $\begin{array}{l}\text { Polypropylene, Prolene, or } \\
\text { allograft (NR trade name) }\end{array}$ & $\begin{array}{l}\text { Anti-incontinence: } \\
\text { 92/124 } \\
\text { Hysterectomy: NR }\end{array}$ & $36 \mathrm{~m}(0-74)$ & $\begin{array}{l}\text { Efficacy } \\
\text { Safety }\end{array}$ \\
\hline Bradley 2007[36] & 305 & NR & NR & NR & Abdominal (open) & Sacrocolpopexy & $\begin{array}{l}\text { Non-absorbable synthetic, } \\
\text { xenograft, autologous or } \\
\text { cadaveric fascia lata }\end{array}$ & $\begin{array}{l}\text { Anti-incontinence: } \\
\text { 148/305 }\end{array}$ & $1 \mathrm{y}$ & $\begin{array}{l}\text { Efficacy } \\
\text { Safety }\end{array}$ \\
\hline $\begin{array}{l}\text { Culligan } \\
\text { 2002[38] }\end{array}$ & 245 & $61(32-83)$ & NR & NR & Abdominal & Sacrocolpopexy & $\begin{array}{l}\text { Synthetic mesh (NR trade } \\
\text { name) }\end{array}$ & $\begin{array}{l}\text { Anti-incontinence: } \\
\text { 171/245 } \\
\text { Hysterectomy: 11/245 }\end{array}$ & $\begin{array}{l}\text { Objective } \\
\text { failure: }>=4 y \text {; } \\
\text { subjective } \\
\text { failure: } 3.3 y(0.8- \\
6.9)\end{array}$ & $\begin{array}{l}\text { Efficacy } \\
\text { Safety }\end{array}$ \\
\hline $\begin{array}{ll}\text { De } & \text { Vries } \\
\text { 1995[39] } & \end{array}$ & 101 & $59(37-82)$ & $15 / 83$ & NR & Abdominal (open) & Sacrocolpopexy & $\begin{array}{l}\text { Polyethylene tetraphalate, } \\
\text { Mersilene (Amid type III) }\end{array}$ & $\begin{array}{l}\text { Anti-incontinence : } \\
\text { 20/101 } \\
\text { Hysterectomy : NR }\end{array}$ & $4 y(1-13)$ & $\begin{array}{l}\text { Efficacy } \\
\text { Safety }\end{array}$ \\
\hline Higgs 2005b[46] & 148 & $58(10)$ & $24 / 123$ & NR & Abdominal (open) & Sacrocolpopexy & $\begin{array}{l}\text { Combined mesh, } \\
\text { polyproglactine and prolene } \\
1: 1 \text {, Vypro; fascia lata; } \\
\text { polypropylene, Prolene; } \\
\text { polyethylene tetraphalate, } \\
\text { Mersilene. }\end{array}$ & $\begin{array}{l}\text { Anti-incontinence : } \\
\text { 76/148 } \\
\text { Hysterectomy : 25/148 }\end{array}$ & 45m (15) & $\begin{array}{l}\text { Efficacy } \\
\text { Safety }\end{array}$ \\
\hline $\begin{array}{l}\text { Lindeque } \\
\text { 2002[51] }\end{array}$ & 262 & $28-79$ & $4 / 258$ & $8 / 254$ & Abdominal (open) & Sacrocolpopexy & $\begin{array}{l}18 \text { dura mater strips, then } \\
\text { changed to } \\
\text { polytetrafluoroethylene, Gore- } \\
\text { Tex (Amid type II) }\end{array}$ & $\begin{array}{l}\text { Anti-incontinence: } \\
\text { 106/262 } \\
\text { Hysterectomy: NR }\end{array}$ & All $>=16 \mathrm{~m}$ & $\begin{array}{l}\text { Efficacy } \\
\text { Safety }\end{array}$ \\
\hline Snyder 1991[57] & 147 & $62(30-83)$ & $3 / 144$ & NR & Abdominal (open) & Sacrocolpopexy & $\begin{array}{l}\text { Dacron graft (NR details); } \\
\text { polytetrafluoroethylene, Gore- } \\
\text { Tex (Amid type II), and other } \\
\text { type of mesh (NR) }\end{array}$ & NR & 43m (1m-17y) & $\begin{array}{l}\text { Efficacy } \\
\text { Safety }\end{array}$ \\
\hline $\begin{array}{l}\text { Timmons } \\
\text { 1992[59] }\end{array}$ & 163 & 58 (19-81) & $163 / 3$ & NR & Abdominal (open) & Sacrocolpopexy & $\begin{array}{l}\text { Fascial lata (NR trade name); } \\
\text { polyethylene tetraphalate, } \\
\text { Mersilene (Amid type III) }\end{array}$ & NR & 33m (9m-18y) & Safety \\
\hline
\end{tabular}




\begin{tabular}{|c|c|c|c|c|c|c|c|c|c|c|}
\hline ID & $\mathbf{N}$ & Age, $y$ & $\begin{array}{l}\text { Uterine/ } \\
\text { vault }\end{array}$ & $\begin{array}{l}\text { Primary/ } \\
\text { secondary }\end{array}$ & Intervention route & Technique & Mesh/graft & Concomitant procedure & Follow up (mean) & Outcomes \\
\hline \multicolumn{11}{|c|}{ Non-randomised comparative studies } \\
\hline $\begin{array}{l}\text { Visco } 2001 \\
\text { [31] }\end{array}$ & $\begin{array}{l}\text { A, } 155 \\
\text { B, } 88 \\
\text { C, } 25 \\
\text { D, } 5\end{array}$ & $\begin{array}{l}A+B+C+D, 61 \\
(31-84)\end{array}$ & NR & NR & $\begin{array}{l}\text { A, abdominal } \\
\text { B, abdominal } \\
\text { C, vaginal+ abdominal } \\
\text { D, vaginal+ abdominal }\end{array}$ & $\begin{array}{l}\text { A, sacrocolpopexy } \\
\text { B, sacrocolpoperineopexy } \\
\text { C, sacrocolpoperineopexy } \\
\text { D, sacrocolpoperineopexy } \\
\text { with mesh placed to vaginal } \\
\text { field }\end{array}$ & $\begin{array}{l}\text { A, polyethylene tetraphalate, } \\
\text { Mersilene (Amid type III) or } \\
\text { Gore-Tex (Amid type II) } \\
\text { B, C, D, same as above }\end{array}$ & $\begin{array}{l}\text { Anti-incontinence: } \\
\text { NR } \\
\text { Hysterectomy: } \\
\text { A+B+C+D: 45/273 }\end{array}$ & $\begin{array}{l}\text { A, 7m (1-87) } \\
\text { B, } 5 \mathrm{~m}(1-45) \\
\text { C, } 6 \mathrm{~m}(1-28) \\
\text { D, } 7 \mathrm{~m}(2-11)\end{array}$ & Safety \\
\hline $\begin{array}{l}\text { Case series } \\
\text { Su } \\
2007[40,58]\end{array}$ & 169 & $62(10)$ & $5 / 164$ & NR & Abdominal + vaginal & Sacrocolpoperineopexy & $\begin{array}{l}\text { Porcine dermis, Pelvicol; } \\
\text { cadaveric fascia, Tutoplast; } \\
\text { polypropylene, Gynemesh, } \\
\text { Prolite, or Prolene (all Amid } \\
\text { type I) }\end{array}$ & $\begin{array}{l}\text { Anti-incontinence: 155/169 } \\
\text { Hysterectomy: 11/169 }\end{array}$ & $14 \mathrm{~m}(1.5-24)$ & $\begin{array}{l}\text { Efficacy } \\
\text { Safety }\end{array}$ \\
\hline
\end{tabular}

NR: not reported 


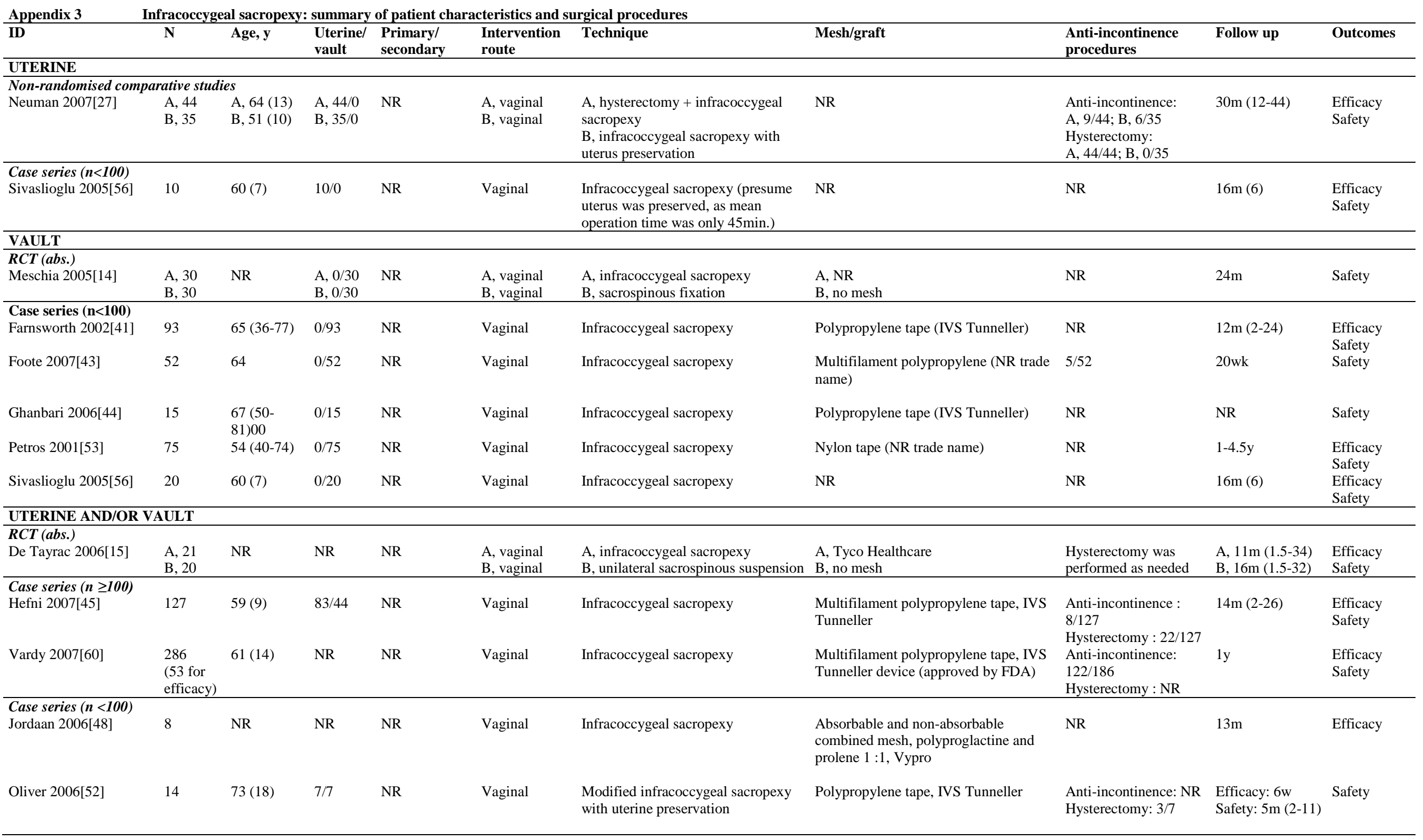




\begin{tabular}{|c|c|c|c|c|c|c|c|c|c|c|}
\hline ID & $\mathbf{N}$ & Age, $y$ & $\begin{array}{l}\text { Uterine/ } \\
\text { vault }\end{array}$ & $\begin{array}{l}\text { Primary/ } \\
\text { secondary }\end{array}$ & $\begin{array}{l}\text { Intervention } \\
\text { route }\end{array}$ & Technique & Mesh/graft & $\begin{array}{l}\text { Anti-incontinence } \\
\text { procedures }\end{array}$ & Follow up & Outcomes \\
\hline Petros 2005[54] & 67 & $65(35-87)$ & $23 / 40$ & NR & Vaginal & $\begin{array}{l}\text { Tissue Fixation System posterior } \\
\text { sling (a direct evolution of the } \\
\text { infracoccygeal sacropexy) }\end{array}$ & $\begin{array}{l}\text { Polypropylene, Tissue Fixation System } \\
\text { device, approved by the Australian and } \\
\text { European Government regulatory } \\
\text { bodies }\end{array}$ & NR & 9m (3-15) & Safety \\
\hline Sentihes 2007[55] & 44 & $66(50-84)$ & $24 / 20$ & NR & Vaginal & $\begin{array}{l}\text { Non-absorbable hammock placement } \\
\text { using anterior trans-obturator and } \\
\text { posterior infracoccygeal extensions }\end{array}$ & $\begin{array}{l}\text { Polyester, Parietex, then changed to } \\
\text { multifilament polypropylene, Surgipro, } \\
\text { then low-weight monofilament } \\
\text { polypropylene, Ugytex }\end{array}$ & $\begin{array}{l}\text { Anti-incontinence: } \\
\text { 0/44 } \\
\text { Hysterectomy: 24/44 }\end{array}$ & $29 \mathrm{~m}(9-47)$ & $\begin{array}{l}\text { Efficacy } \\
\text { Safety }\end{array}$ \\
\hline
\end{tabular}




\begin{tabular}{|c|c|c|c|c|c|c|c|c|c|c|}
\hline ID & $\mathbf{N}$ & Age, $y$ & $\begin{array}{l}\text { Uterine/ } \\
\text { vault }\end{array}$ & $\begin{array}{l}\text { Primary/ } \\
\text { secondary }\end{array}$ & Intervention route & Technique & Mesh/graft & Concomitant procedure & Follow up (mean) & Outcomes \\
\hline $\begin{array}{l}\text { RCT } \\
\text { Roovers } \\
\text { 2004[12] }\end{array}$ & $\begin{array}{l}\text { A, } 41 \\
\text { B, } 41\end{array}$ & $\begin{array}{l}\text { A, } 58 \text { (9) } \\
\text { B, } 56 \text { (11) }\end{array}$ & $\begin{array}{l}\text { A, } 41 / 0 \\
\text { B, } 41 / 0\end{array}$ & NR & $\begin{array}{l}\text { A, abdominal } \\
\text { B, vaginal }\end{array}$ & $\begin{array}{l}\text { A, sacrohysteropexy } \\
\text { B, hysterectomy + anterior } \\
\text { and/or posterior colporrhaphy }\end{array}$ & $\begin{array}{l}\text { A, polypropylene, Gore-Tex } \\
\text { (Amid type II) } \\
\text { B, no mesh }\end{array}$ & $\begin{array}{l}\text { Anti-incontinence: } \\
\text { A, 16/41; B,11/41 } \\
\text { Hysterectomy: } \\
\text { A, 2/41 (B was performed); B, } \\
\text { 41/41 }\end{array}$ & $1 \mathrm{y}$ & $\begin{array}{l}\text { Efficacy } \\
\text { Safety }\end{array}$ \\
\hline $\begin{array}{l}\text { Non-randomise } \\
\text { Costantini } \\
\text { 2005[19] }\end{array}$ & $\begin{array}{l}\text { compa } \\
\text { A, } 36 \\
\text { B, } 39\end{array}$ & $\begin{array}{l}\text { ative studies } \\
\text { A, } 61(12) \\
\text { B, } 62(8)\end{array}$ & $\begin{array}{l}\text { A, } 36 / 0 \\
\text { B, } 39 / 0\end{array}$ & NR & $\begin{array}{l}\text { A, abdominal } \\
\text { B, abdominal }\end{array}$ & $\begin{array}{l}\text { A, sacrohysteropexy } \\
\text { B, hysterectomy + sacropexy }\end{array}$ & $\begin{array}{l}\text { A, polypropylene, Marlex } \\
\text { (Amid type I) } \\
\text { B, same as A }\end{array}$ & $\begin{array}{l}\text { Anti-incontinence: } \\
\text { A, 28/36; B, 30/39 } \\
\text { Hysterectomy: } \\
\text { A, 0/36; B, 39/39 } \\
\end{array}$ & 51m (12-115) & $\begin{array}{l}\text { Efficacy } \\
\text { Safety }\end{array}$ \\
\hline $\begin{array}{l}\text { Case series (n < } \\
\text { Banu 1997[33] }\end{array}$ & $\begin{array}{r}100) \\
19\end{array}$ & $17-27$ & $19 / 0$ & NR & Abdominal (open) & Sacrohysteropexy & $\begin{array}{l}\text { Polyester, Mersilene (Amid } \\
\text { type III) }\end{array}$ & Hysterectomy: 0/19 & $3-5 y$ & $\begin{array}{l}\text { Efficacy } \\
\text { Safety }\end{array}$ \\
\hline $\begin{array}{l}\text { Barranger } \\
\text { 2003[34] }\end{array}$ & 30 & $35.7(29-43)$ & $30 / 0$ & $29 / 1$ & Abdominal (open) & Sacrohysteropexy & Polyester, Mersuture & $\begin{array}{l}\text { Anti-incontinence: } 30 / 30 \\
\text { Hysterectomy: 0/30 }\end{array}$ & $\begin{array}{l}\text { Efficacy: 44.5m (2- } \\
\text { 156); } \\
\text { Safety: } 94.6 \mathrm{~m}(8- \\
160)\end{array}$ & $\begin{array}{l}\text { Efficacy } \\
\text { Safety }\end{array}$ \\
\hline Leron 2001[50] & 13 & $39(27-60)$ & $13 / 0$ & NR & Abdominal (open) & Sacrohysteropexy & $\begin{array}{l}\text { Non-absorbable synthetic } \\
\text { mesh, Teflon }\end{array}$ & $\begin{array}{l}\text { Anti-incontinence: } 4 / 13 \\
\text { Hysterectomy: } 0 / 13\end{array}$ & $16 m(4-49)$ & $\begin{array}{l}\text { Efficacy } \\
\text { Safety }\end{array}$ \\
\hline Joshi 1993[49] & 20 & $27.5(17-32)$ & $20 / 0$ & $19 / 1$ & Abdominal (open) & $\begin{array}{l}\text { Uterine suspension sling (uterus } \\
\text { is suspended to the pectineal } \\
\text { ligaments) }\end{array}$ & $\begin{array}{l}\text { Non-absorbable synthetic } \\
\text { mesh, Mersilene (Amid type } \\
\text { III) }\end{array}$ & $\begin{array}{l}\text { Anti-incontinence: } 5 / 20 \\
\text { Hysterectomy: 0/19 }\end{array}$ & $6-30 m$ & $\begin{array}{l}\text { Efficacy } \\
\text { Safety }\end{array}$ \\
\hline
\end{tabular}

NR: not reported 


\section{Figure S1 Summary of quality assessment of the RCTs (full text, n=5)}

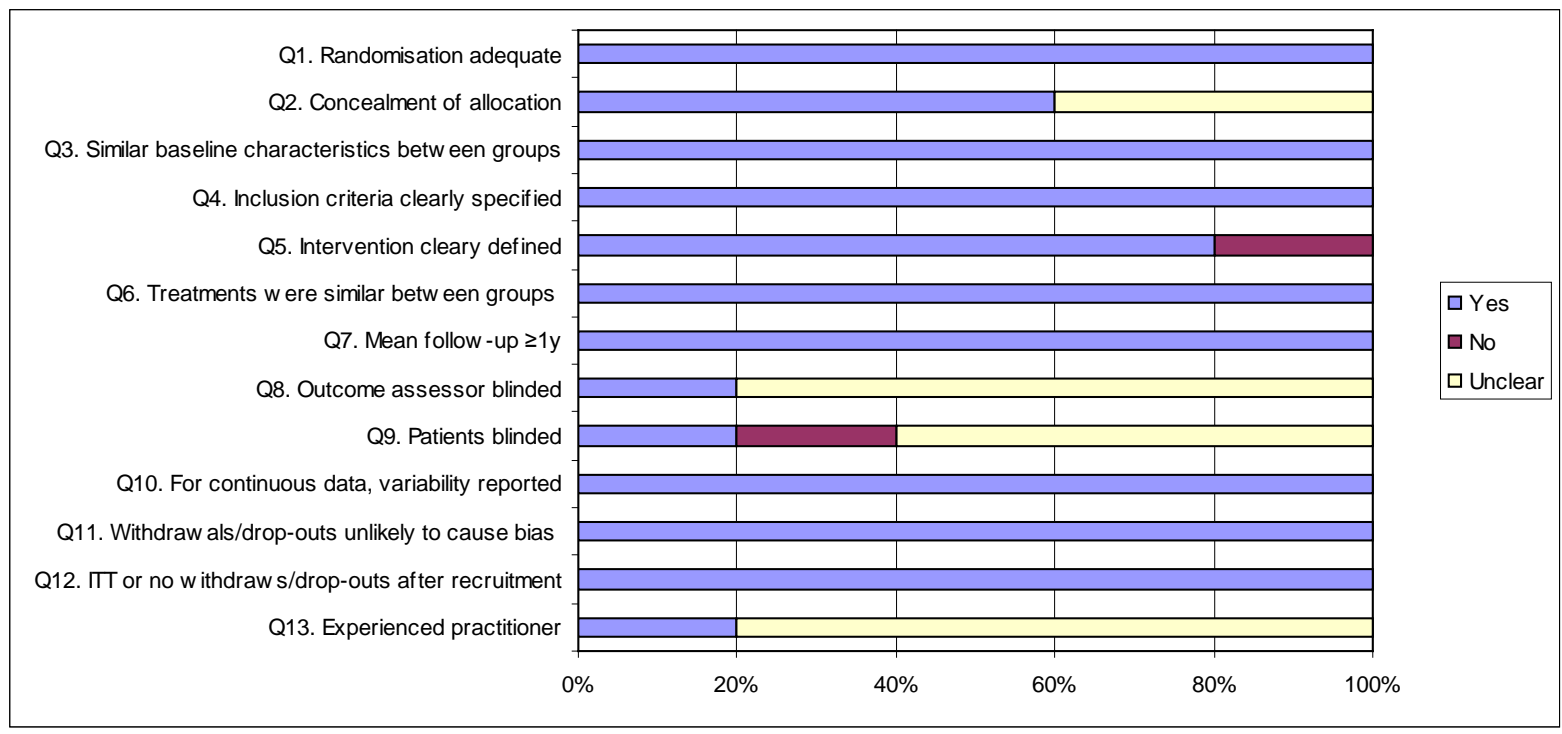

Figure S2 Summary of quality assessment of the non-randomised comparative studies $(\mathbf{n}=17)$

Q1. Participant representativeness

Q2. Participant inclusion/exclusion criteria described

Q3. Similar participant baseline characteristics

Q4. Selection of patients was consecutive

Q5. Data collection w as undertaken prospectively

Q6. Similar baseline characteristics betw een groups

Q7. Intervention clearly defined

Q8. Experienced practitioner

Q9. Appropriate treatment place

Q10. Important outcomes considered

Q11.Objective outcome measures used

Q12. Outcome assessor blinded

Q13. Mean follow -up $\geq 1 y$

Q14. Information provided on non-respondents/drop-outs

Q15. Withdraw als/drop-outs unlikely to cause bias

Q16. Follow -up similar betw een groups

Q17. Important prognostic factors identified

Q18. Analyses adjusted for confounding factors

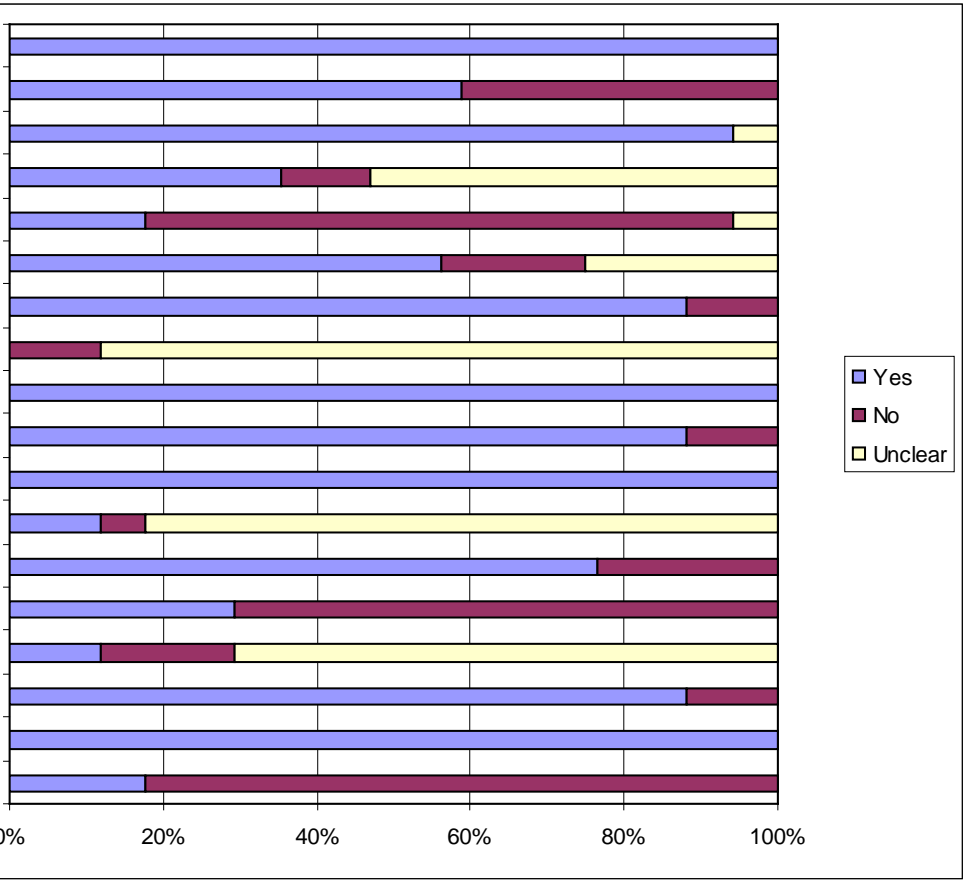


Figure S3 Summary of quality assessment of the case series $(n=29)$

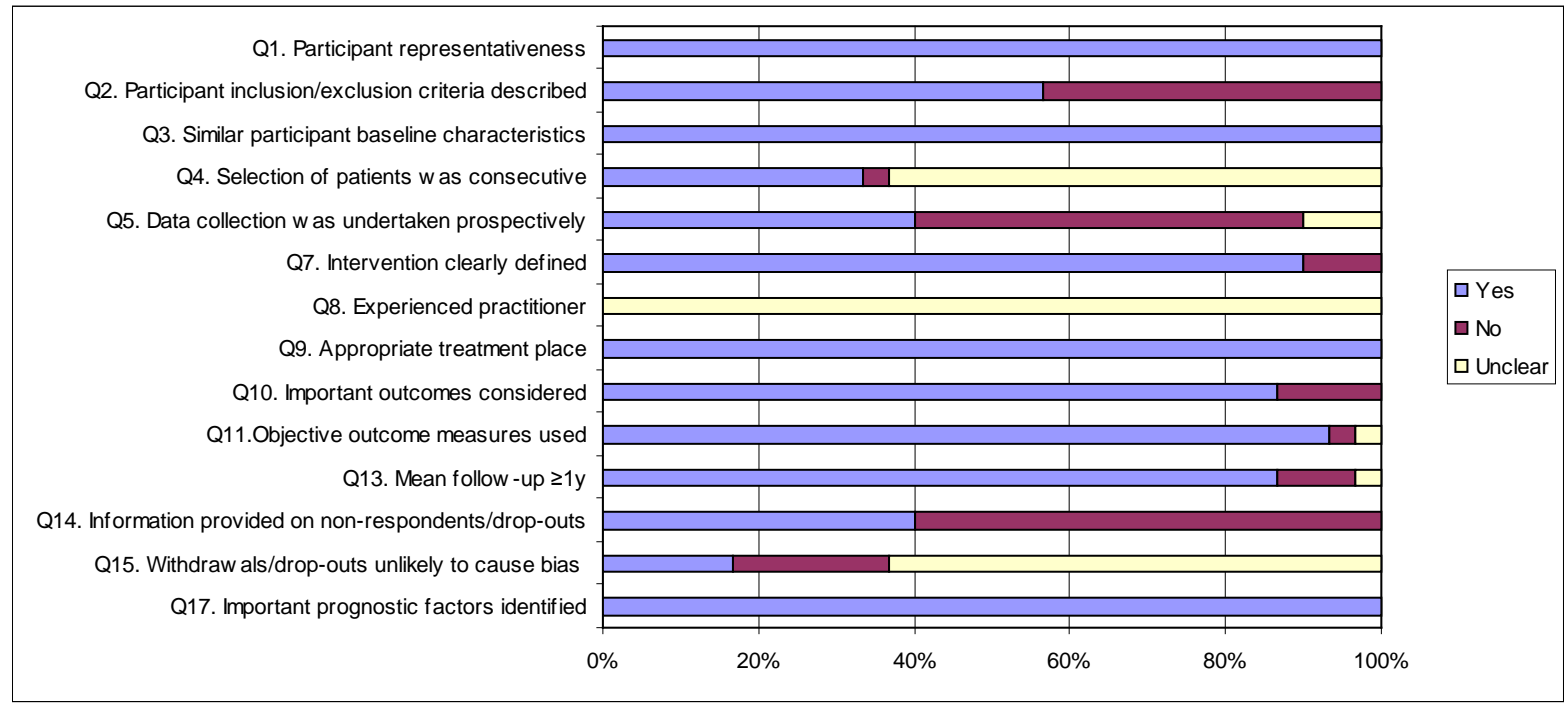

